DOI: 10.32089/WBH.PHW.2020.3(273).0004

orcid.org/0000-0002-8096-0014

Marek Bogdan Kozubel

(Biuro Edukacji Narodowej Instytutu Pamięci Narodowej)

\title{
3 Żelazna Dywizja Strzelecka Armii Ukraińskiej Republiki Ludowej w 1920 r. Zarys szlaku bojowego w wojnie polsko-bolszewickiej
}

Sojusz polsko-ukraiński z 1920 r. doczekał się w Polsce bardzo wielu opracowań. Ich autorzy podjęli się opisania różnych aspektów współpracy polityczno-militarnej, wymierzonej przeciwko Rosji bolszewickiej. Najwięcej uwagi poświęcono formowaniu i szlakowi bojowemu Armii Ukraińskiej Republiki Ludowej (URL) ${ }^{1}$. Jednak niewiele publikacji poświęcono poszczególnym formacjom ukraińskim. Wyjątkiem jest jedynie opracowanie Emiliana Wiszki o 6 Siczowej Dywizji Strzeleckiej (DS) ${ }^{2}$.

Tematem mojego artykułu jest sformowanie i szlak bojowy innej znanej dywizji ukraińskiej - 3, zwanej też Żelazną. Po raz pierwszy jednostkę o tej nazwie sformowano w czerwcu 1919 r., gdy Armia URL toczyła zacięte walki z Armią Czerwoną na Podolu. Pod dowództwem płk. Ołeksandra

${ }^{1}$ Z. Karpus, Jeńcy i internowani rosyjscy i ukrainscy na terenie Polski w latach 1918-1924, Toruń 1997; idem, Wschodni sojusznicy Polski w wojnie 1920 roku: oddzialy wojskowe ukraińskie, rosyjskie, kozackie i białoruskie w Polsce w latach 1919-1920, Toruń 1999; R. Potocki, Idea restytucji Ukraińskiej Republiki Ludowej: (1920-1939), Lublin 1999; J. Ślipiec, Drogi niepodległości - Polska i Ukraina 1919-1921, Warszawa 1999; J. J. Bruski, Petlurowcy. Centrum Państwowe Ukraińskiej Republiki Ludowej na wychodźstwie (1919-1924), Kraków 2000; J. Legieć, Armia Ukraińskiej Republiki Ludowej w wojnie polsko-ukraińsko-bolszewickiej w 1920 r., wyd. 2, Toruń 2002; J. Pisuliński, Nie tylko Petlura. Kwestia ukraińska w polskiej polityce zagranicznej w latach 1918-1923, Wrocław 2004; S. Szajdak, Polsko-ukraiński sojusz polityczno-wojskowy w 1920 roku, Warszawa 2005; A. Rukkas, Razem z Wojskiem Polskim. Armia Ukraińskiej Republiki Ludowej w 1920 r., Warszawa 2020.

2 E. Wiszka, Szósta Strzelecka. Szósta Siczowa Dywizja Strzelecka Armii Ukraińskiej Republiki Ludowej. Formowanie, szlak bojowy, internowanie 1920-1924, Toruń 2012. 
Udowyczenki ${ }^{3}$ natychmiast odniosła szereg sukcesów na polu walki i stała się jedną z najskuteczniejszych dywizji ukraińskich. Po wyparciu bolszewików z Ukrainy Prawobrzeżnej walczyła przeciwko Siłom Zbrojnym Południa Rosji (SZPR). Poniosła wtedy bardzo ciężkie straty. Osłabiła ją również szalejąca nad Dnieprem epidemia tyfusu. 3 Żelazna Dywizja Strzelecka została w końcu rozbita na początku I Pochodu Zimowego ${ }^{4}$ Armii Czynnej URL w grudniu $1919 \mathrm{r}^{5}$

Za podstawę do napisania tego artykułu posłużyły mi wydawnictwa źródłowe, relacje ukraińskich oficerów oraz polskie i ukraińskie opracowania poświęcone Armii URL i wojnie polsko-bolszewickiej 1919-1920. Szczególnie cenne okazały się dokumenty z zasobów Centralnego Archiwum Wojskowego Wojskowego Biura Historycznego, opublikowane w wydawnictwach źródłowych pt. Bitwa lwowska ${ }^{6}$, Bitwa o Ukrainę ${ }^{7}$, Bitwa wołyńsko-podolska ${ }^{8}$ oraz Ukrajinśko-moskowśka wijna $1920 r .{ }^{9}$ Wiele informacji wnoszą również dokumenty znajdujące się w zasobach Centralnego Państwowego Archiwum Wyższych Organów Władzy i Administracji Ukrainy w Kijowie (Centralnyj Derzawnyj Archiw Wyszczych Orhaniw Włady i Uprawlinnja Ukrajiny w Kyjewi). Nie można też pominąć bardzo cennych wspomnień gen. Ołeksandra Udowyczenki, dowódcy 3 Żelaznej DS, w których przedstawiono dosyć szczegółowo szlak bojowy tej formacji ${ }^{10}$.

3 Ukraińskie nazwiska zostały zapisane zgodnie z sugestiami zawartymi w publikacji: E. Wiszka, Jak przekazywać teksty ukraińskie w języku polskim?, „Nad Wisłą i Dnieprem. Polska i Ukraina w przestrzeni europejskiej - przeszłość i teraźniejszość” (Toruń-Kijów) 2002, nr 1.

4 I Pochód Zimowy Armii Czynnej URL 1919-1920 - operacja Armii Czynnej URL, której celem było wyjście na tyły Sił Zbrojnych Południa Rosji i prowadzenie tam walki partyzanckiej. Na początku 1920 r. oddziały ukraińskie zaczęły walczyć z Armią Czerwoną, która systematycznie wypierała z Ukrainy wojska „białogwardyjskie”. Więcej informacji nt. I Pochodu Zimowego można znaleźć w następujących pozycjach: O. Docenko, Zymowyj pochid (6 XII 1919 - 6 V 1920), Kyjiw 2001; J. Legieć, Armia..., s. 41-55.

5 Więcej informacji na temat szlaku bojowego 3 Żelaznej DS w 1919 r. zob. O. Udowyczenko, Tretja Zalizna dywizja. Materiały do istorii Wijśka Ukrainśkoji Narodnoji Respublyky. Rik 1919, New York 1971.

${ }^{6}$ Bitwa lwowska 25 VII-18 X 1920. Dokumenty operacyjne, t. I: 25 VII-5 VIII, oprac. zesp. pod kier. M. Tarczyńskiego, Warszawa 2002; t. II: 6-20 VIII, oprac. eidem, Warszawa 2004.

7 Bitwa o Ukraine 1 I - 24 VII 1920. Dokumenty operacyjne, t. I: 1 I - 11 V 1920, oprac. eidem, Warszawa 2016.

8 Bitwa wolyńsko-podolska 5 IX-21 X 1920. Dokumenty operacyjne, oprac. eidem, Warszawa 2014 .

9 Ukrajinśko-moskowśka wijna 1920 r., oprac. W. Salski, P. Szandruk, Warszawa 1933.

${ }_{10}$ O. Udowyczenko, Tretja Zalizna dywizja. Materiały do istorii Wijśka Ukrainśkoji Narodnoji Respubłyky. Rik 1920, New York 1982. W dalszej części artykułu cytowana będzie wyłącznie ta część wspomnień gen. Udowyczenki. 


\section{Odtworzenie 3 Żelaznej Dywizji Strzeleckiej}

Na przełomie 1919 i 1920 r. zaistniała możliwość utworzenia formacji ukraińskich przy wsparciu Polski oraz cofających się pod naporem Armii Czerwonej SZPR. Plan budowy ukraińskich dywizji zyskał poparcie szczególnie polskich wojskowych. Sojusz Polski z URL był korzystny zwłaszcza z militarnego punktu widzenia. Dzięki niemu front przeciwbolszewicki zostałby skrócony. Dodatkowo Ukraina służyłaby jako bufor oddzielający młode państwo polskie od Rosji ${ }^{11}$.

Nowe formacje ukraińskie w Polsce można było formować w oparciu o dwa źródła: obozy jenieckie i obozy dla internowanych (m.in. w Łańcucie) oraz z rejonu Kamieńca Podolskiego, gdzie przybywała znaczna liczba oficerów i kozaków, którzy nie zostali internowani. Na terenie Polski przebywało w tym czasie ok. 3,5-4 tys. Ukraińców, którzy mogli zostać wcieleni do tworzonych oddziałów. Znaczna część $\mathrm{z}$ nich była jednak chora lub ranna ${ }^{12}$.

Zastój $w$ formowaniu nowych oddziałów był spowodowany z jednej strony niechęcią Ententy do URL, a z drugiej chęcią zmuszenia strony ukraińskiej przez polskie władze do większych ustępstw. Dopiero od końca lutego 1920 r. ruszyły prace nad tworzeniem wojsk ukraińskich w Polsce. Organizatorzy skupili się początkowo głównie na opracowaniu struktur dywizji ukraińskich, których miało być osiem. Formacje z numerami 1-5 miały powstać na bazie Armii Czynnej gen. Mychajła Omelianowycza-Pawłenki, która uczestniczyła w tym czasie w I Pochodzie Zimowym; o numerach 6-7 $\mathrm{w}$ Polsce, a ta z nr. $8 \mathrm{w}$ Rumunii. Struktura ukraińskiej dywizji piechoty miała być podobna, ale nie identyczna, do jej bolszewickiego odpowiednika: trzy brygady piechoty (w ukraińskim przypadku każda w sile trzech kureni ${ }^{13}$ zamiast pułków), brygada artylerii, pułk kawalerii i oddziały tyłowe ${ }^{14}$.

Na początku stycznia 1920 r. Ukraińcy, po akceptacji ich planu przez stronę polską, rozpoczęli formowanie brygady na Podolu i dywizji piechoty w Łańcucie. Pierwsza z formacji weszła później w skład reaktywowanej 3 Żelaznej DS. Dowódcą II Brygady Podolskiej mianowano 2 lutego płk. Ołeksandra Szapowała. Według jego szacunków można było zebrać na terenie Kamieńca i okolic ok. 200 oficerów i 800 kozaków. Nowo tworzona formacja nie otrzymała jednak jeszcze mundurów i broni ${ }^{15}$.

${ }_{11}$ Z. Karpus, Jeńcy..., s. 84; J. Legieć, Armia..., s. 55-56; S. Szajdak, Polsko-ukraiński..., s. 111.

12 Ukrajinśko-moskowśka..., s. 2.

${ }_{13}$ Kureń - jednostka będąca odpowiednikiem batalionu.

14 J. Legieć, Armia..., s. 58-59.

15 P. Szandruk, Siła męstwa, Warszawa-Kraków 2014, s. 103; J. Legieć, Armia..., s. 57. 
Ostatecznie płk. Szapowałowi udało się zebrać 300 oficerów i kozaków. $Z$ racji tego formacja była określana przez Polaków mianem „baonu” (batalionu). Ze względu na braki w umundurowaniu i uzbrojeniu jego podwładni nie mogli wziąć udziału w walce, jednak dzięki skoszarowaniu nie doszło do ich demoralizacji ${ }^{16}$.

Z pomysłem tworzenia ukraińskich formacji wystąpiła również 18 stycznia 1920 r. strona rosyjska za pośrednictwem angielskiej misji wojskowej w Odessie. Tego dnia zaproponowano płk. Udowyczence sformowanie pułków ukraińskich mających walczyć za Białą Rosję. Anglicy obiecywali dostarczyć broń, mundury i sprzęt na wyekwipowanie ok. 20 tys. Ukraińców (w tym żołnierzy z brygad halickich) znajdujących się w Odessie i jej okolicach. Pułkownik Udowyczenko wystąpił z kontrpropozycją, która zakładała oddanie wszystkich ukraińskich formacji w rejonie Odessy pod jego dowództwo i wycofanie się SZPR z Ukrainy. Początkowo Rosjanie nie chcieli zaakceptować tych warunków, jednak pod wpływem własnych porażek zostali zmuszeni do ich przyjęcia ${ }^{17}$.

Na przełomie stycznia i lutego 1920 r., gdy Armia Czerwona była już pod Odessą, płk Udowyczenko wraz z 48 żołnierzami narodowości ukraińskiej podjął decyzję o opuszczeniu miasta. Jego zamiarem było początkowo połączenie się z Armią Czynną URL będącą w pochodzie zimowym, lecz nie mogąc ustalić miejsca jej przebywania, wyruszył wzdłuż Dniestru w kierunku polskich pozycji. Pod Tyraspolem jego oddział został napadnięty przez bolszewików. Wraz z pięcioma ocalałymi ludźmi, 5 lutego, płk Udowyczenko dotarł do Mohylewa Podolskiego, gdzie objął dowództwo nad ukraińską załogą miasta (20-25 kozaków i oficerów) oraz oddziałem halickim złożonym z ok. 100 wyleczonych z tyfusu strzelców. 18 lutego Mohylew odwiedził premier rządu URL Izaak Mazepa i polecił pułkownikowi sformowanie samodzielnej brygady piechoty na terenie powiatów mohylewskiego i jampolskiego. Potrzebną do uzbrojenia rekrutów broń odbierano rosyjskim żołnierzom ze zdemoralizowanego korpusu gen. Nikołaja Bredowa, który wycofywał się w kierunku polskich pozycji ${ }^{18}$.

Do dnia 5 marca 1920 r. w składzie brygady znalazły się: Pułk Mohylewski (300 bagnetów), Kureń Halicki (100 bagnetów) i Konna Brygada atamana Bohusława Szaszkewycza (200 szabel i jedno działo). Formacja nie miała jednak całkowicie regularnego charakteru. Tego samego dnia Udowyczenko, zagrożony okrążeniem przez wroga, zdecydował się opuścić ze swym oddziałem Mohylew Podolski i udać się w kierunku Kamieńca Podolskiego. 7 marca Brygada Mohylewska dotarła na miejsce, gdzie płk Udowyczenko

16 J. Legieć, Armia..., s. 63.

17 O. Udowyczenko, Tretja Zalizna..., s. 34-35.

18 Ibidem, s. 37-39; J. Legieć, Armia..., s. 64. 
nawiązał kontakt z polskim dowództwem. Następnego dnia pod wsią Stawczany brygada starła się z oddziałem bolszewickim i z powodu braku amunicji wycofała się do Filipy, obsadzonej przez polską 18 Dywizję Piechoty (DP). Po wzmocnieniu brygady kompanią z polskiego 149 Pułku Piechoty (pp) Ukraińcy uderzyli na Iwankowce. W zajętej wsi pozostał oddział ukraiński w sile ok. 200 bagnetów. W starciach poległo dwóch kozaków, a ośmiu zostało rannych. Polska kompania nie poniosła strat ${ }^{19}$.

17 marca 1920 r. w wyniku porozumienia zawartego pomiędzy Naczelnym Dowództwem Wojska Polskiego (NDWP) a Głównym Atamanem Armii URL Symonem Petlurą brygadę płk. Udowyczenki podporządkowano dowódcy 18 DP, gen. Franciszkowi Krajowskiemu, oraz wydano rozkaz demobilizacji formacji halickich, wchodzących w skład brygady. Petlura wydał także rozkaz podporządkowania "grupie” tegoż oficera „Baonu” Szapowała. Jego dowódca został oddany do dyspozycji płk. Udowyczenki ${ }^{20}$.

Jeszcze 17 marca 1920 r. gen. Krajowski udzielił pochwały „grupie” ukraińskiego oficera: „Bratnie Wojska Ukraińskie stojące też na naszym przedpolu z swoim d-cą Pułkownikiem Udowiczenką dały przykład męstwa i odwagi. Kawaleria 4 Brygady Strzeleckiej gen. [w tym wypadku nadinterpretowano stopień funkcyjny atamana - M. K.] Szapowała swoją lotnością i inicjatywą uświetniła nasze zwycięstwo. Z najwyższą radością przychodzi mi dziś wyrazić oficerom i żołnierzom moje podziękowanie i pochwałę za mężne opieranie się wspólnemu wrogowi"21.

20 lub 24 marca 1920 r. płk Udowyczenko otrzymał od ministra spraw wojskowych URL płk. Wołodymyra Salskiego rozkaz sformowania dywizji strzeleckiej, w skład której miały wejść znajdujące się w okolicy oddziały ukraińskie. Poza Brygadą Podolską był to m.in. Konny Kureń im. atamana Iwana Sirki. Udowyczenko otrzymał również nominację na jej dowódcę. Formacja otrzymała numer porządkowy „2”. Składała się z dwóch brygad:

19 Dok. Nr 111. Wyciagg z meldunku sytuacyjnego z dnia 9 III 1920 r., Warszawa, 10 III 1920 r. [w:] Bitwa o Ukraine..., s. 297; O. Udowyczenko, Tretja Zalizna..., s. 39-40; Z. Karpus, Wschodni..., s. 22; J. Legieć, Armia..., s. 64 i 66.

20 Dok. Nr 136. Dow[ówdztwo] Fr[ontu] Podolskiego Oddział II (Hughes) MSWojsk. Dep[artament] II (pismo), Warszawa, 17 III 1920 r. [w:] Bitwa o Ukraine..., s. 334-335. W ściśle tajnym raporcie stwierdzono: „Akt ten pod względem politycznym jest dla Nacz[elnego]. Dow[ództwa]. najzupełniej wystarczający, demobilizacja oddziałów galicyjskich, wchodzących w skład grupy Wdowiczenki [powinno być „Udowyczenki”] (zresztą bardzo nielicznych), które w ostatnich walkach zadokumentowały swój antybolszewizm, da możność rozstrzygnięcia tej sprawy łagodnie, jak dla nas tak też dla Ukraińców nie osłabiając na razie ich siły zbrojnej, znajdującej się obecnie w stadium organizacyjnym; biorąc to pod uwagę korzystne będzie, aby gen. Krajowski nawiązał ścisłą łączność z grupą Wdowiczenki, zasilając takową amunicją", zob. ibidem, s. 334.

${ }^{21}$ Dok. Nr 137. Do Grupy płk. Udowiczenki, b.m., 17 III 1920 r. [w:] Bitwa o Ukrainę..., s. $335-336$. 
IV rozbudowanej w oparciu o „Baon” Szapowała oraz V stworzonej z Brygady Mohylewskiej i pozostałych mniejszych oddziałów. Stanowisko dowódcy IV Brygady objął ppłk Pawło Szandruk, a V ppłk Roman Burkiwski. Z powodu braku odpowiedniej ilości sprzętu i wyszkolonej kadry udało się sformować tylko 4 Pułk Artylerii - pod dowództwem sotnyka ${ }^{22}$ Wołodymyra Rudaniwskiego - zamiast brygady. Dodatkowo w składzie dywizji znalazł się Pułk Techniczny ppłk. Pafnutija Charczenki. Aby usprawnić proces formowania 2 Dywizji, płk Udowyczenko wydał ppłk. Szandrukowi rozkaz wymarszu jego brygady z Kamieńca Podolskiego w rejon Dunajowiec-Żwańczyk-Stara Uszyca, gdzie stacjonowała V Brygada. Oficerowie i kozacy, którzy nie byli jeszcze gotowi do walki, zostali w Kamieńcu, gdzie utworzono z nich II Brygadę Zapasową. Miała ona być formacją, z której przychodziłyby uzupełnienia dla 2 Dywizji ${ }^{23}$.

Bardzo ważnym dla Brygady Mohylewskiej wydarzeniem było internowanie na polskim terytorium korpusu gen. Bredowa. W ten sposób Wojsko Polskie weszło w posiadanie m.in.:

- 6990 rosyjskich i 511 innych sprawnych karabinów powtarzalnych,

- 597 rosyjskich i 180 innych zepsutych karabinów powtarzalnych,

- 2018 sprawnych i 31 zepsutych karabinków produkcji rosyjskiej,

- 251 sprawnych i 92 zepsutych karabinków innej produkcji,

- 168 rewolwerów i pistoletów,

- 325 tys. nabojów karabinowych,

- 438 nabojów do rewolwerów i pistoletów,

- 550 szabel,

- 200 karabinów maszynowych Maxim, 204 Lewis, 49 Colt, 75 Vickers i 8 Schwarzlose,

- 18 dział rosyjskich (kal. 76,2 mm) wz. 1902, 3 dział produkcji brytyjskiej, 3 rosyjskich armatek górskich i 2 haubic ${ }^{24}$.

${ }^{22}$ Ukr. сотнuк - w dokładnym tłumaczeniu setnik; stopień w wojska kozackich, później także formacjach kozackich armii Imperium Rosyjskiego odpowiadający stopniowi porucznika. W wojskach Armii Czynnej był to stopień, którego odpowiednikiem był rotmistrz (kapitan) w ówczesnym Wojsku Polskim.

${ }^{23}$ O. Udowyczenko, Tretja Zalizna..., s. 41; P. Szandruk, Siła..., s. 104-105; Z. Karpus, Jeńcy..., s. 85; J. Legieć, Armia..., s. 67-69; A. Rukkas, Razem..., s. 243.29 III 1920 r. 2 Dywizja została podporządkowana dowódcy $18 \mathrm{DP}$, podobnie jak wcześniej brygada płk. Udowyczenki; zob. A. Rukkas, Razem..., s. 243. Wywiad Armii Czerwonej posiadał w tym czasie dosyć mgliste pojęcie o składzie tej formacji: Dok. $n r$ 26. Razwiedywatielnaja swodka sztaba 14-j Armii s 16 po 31 marta 1920 g. o sastawie i dislokacii biełopolskich i petlurowskich wojsk, b.m., 1 IV 1920 r. [w:] Grażdanskaja wajna na Ukrainie 1918-1920. Sbornik dokumentów i materiałów w triech tomach, czetyriech knigach, t. III, oprac. N. Kolesnik, Kiev 1967, s. 26.

${ }_{24}$ Dok. Nr 157. Ogólne zestawienie materiału uzbrojenia przejętych w Armii gen. Bredowa, Jarmolińce, 26 III 1920 r. [w:] Bitwa o Ukrainę..., s. 374-375. 
Do 26 marca przekazano brygadzie płk. Udowyczenki 1750 rosyjskich karabinów powtarzalnych, 24 karabiny maszynowe Maxim i 8 dział rosyjskich wz. 1902, 200 szabel i 83930 nabojów do karabinów. Dodatkowo wielu Ukraińców, których wcześniej przymusowo wcielono do formacji rosyjskich, wyraziło chęć wstąpienia do brygady płk. Udowyczenki. Przyłączyły się do niej również: cały 42 Pułk Kozaków Dońskich esauła ${ }^{25}$ Michaiła Frołowa i sotnia kozaków kubańskich. Sformowano z nich 2 Pułk Kawaleriii ${ }^{26}$.

O ile w kwestii uzbrojenia sytuacja 2 Dywizji wyglądała dobrze, to bardzo dużym problemem był niedostatek mundurów oraz bielizny. W związku z brakiem dostaw umundurowania od strony polskiej płk Udowyczenko rozkazał zorganizowanie zakładów krawieckich i szewskich, które brały surowce z wytwórni sukna w Dunajowcach i pobliskich garbarni. Zabiegi te pozwoliły jednolicie umundurować dużą liczbę żołnierzy ${ }^{27}$. Sukces ukraińskiego dowódcy potwierdził przedstawiciel NDWP, ppor. Edmund Farenholc, który pod koniec marca 1920 r. wizytował 2 Dywizję. Stwierdził, że jest ona gotowa wyruszyć na front ${ }^{28}$.

1 kwietnia 1920 r. stan żywieniowy 2 Dywizji wynosił 174 oficerów, 658 kozaków i 333 konie (221 wierzchowców, 23 konie artyleryjskie i 99 taborowych). Stan bojowy wynosił z kolei 59 oficerów, 292 bagnety, 15 karabinów maszynowych i 2 haubice ${ }^{29}$. Z niewiadomych powodów w stanie liczebnym nie odnotowano wspomnianych wcześniej 8 dział polowych. Być może powodem były problemy ze sformowaniem oddziału artylerii - brak odpowiedniej liczby artylerzystów oraz wyposażenia ${ }^{30}$.

Z powyższego wynika, że w tym czasie 2 Dywizja nie była jeszcze znaczącą siłą na froncie. Otrzymane uzbrojenie i dostęp do umundurowania pozwalały jednak na rozbudowanie formacji. Według mjr. Walerego Sławka: „Wojska ukraińskie Udowiczenki są - wedle charakterystyki gen. Krajowskiego

${ }_{25}$ Stopień oficerski w formacjach kozackich Imperium Rosyjskiego, odpowiadał stopniowi rotmistrza/kapitana.

26 Dok. Nr 136. Dow[ówdztwo] Fr[ontu] Podolskiego Oddział II (Hughes) MSWojsk. Dep[artament] II (pismo), Warszawa, 17 III 1920 r. [w:] ibidem, s. 335; O. Udowyczenko, Tretja Zalizna..., s. 39-40; Z. Karpus, Wschodni..., s. 22-23; idem, Jeńcy..., s. 85; J. Legieć, Armia..., s. 66-67.

27 P. Szandruk, Siła..., s. 105; J. Legieć, Armia..., s. 67.

28 A. Rukkas, Razem..., s. 243.

${ }^{29}$ Dok. Nr 184. Stan liczebny 6 Armii w dniu 1 IV 1920 r., b.m., 1 IV 1920 r. [w:] Bitwa o Ukrainę..., s. 432.

30 Problem z brakiem odpowiedniej liczby artylerzystów potwierdza rozkaz $\mathrm{nr} 8 \mathrm{płk}$. Udowyczenki z dn. 13 IV 1920 r.: „Jeszcze raz nakazuję dowódcom pieszych kureni dywizji niezwłocznie wydzielić wszystkich artylerzystów, którzy są jeszcze w kureniach i w dalszym ciągu artylerzystów nie zatrzymywać ale przesyłać do sztabu dywizji dla skierowania ich do pułku artylerii" - zob. Dok. Nr 300. Rozkaz L. 8, Żwańczyk, 13 IV 1920 r. [w:] ibidem, s. 605. 
- marne i mogą być tolerowane li tylko jako atut polityczny - jako siła bojowa wartości nie przedstawiają żadnej. Zostałyby z tego powodu wycofane z frontu jeszcze przed nadejściem odpowiedniego zarządzenia Nacz[elnego]. Dow[ówdztwa]"31.

Wbrew protekcjonalnym stwierdzeniom dowódcy 18 DP na początku kwietnia 1920 r. 2 Dywizja stacjonowała blisko frontu i część jej oddziałów brała udział w starciach z bolszewikami. 1 kwietnia Dywizja uczestniczyła w udanym ataku na wsie Kałus, Iwaszkowce i Kucza, a 3 kwietnia została zaatakowana z zaskoczenia (wynik tego starcia nie jest znany). Polskie dowództwo przygotowywało się do ofensywy przeciwko Armii Czerwonej na Ukrainie, którą później nazwano „wyprawą kijowską”. W operacji obok polskich formacji miały wziąć udział dywizje ukraińskie - 2 i 6 Siczowa DS. Przed rozpoczęciem ofensywy 2 DS liczyła już w stanie żywieniowym 317 oficerów, 1462 kozaków, 29 karabinów maszynowych i 7 sprawnych dział. W tym czasie była ona podporządkowana dowództwu 6 Armii $^{32}$.

\section{Udział 2 Dywizji Strzeleckiej w ofensywie na Kijów i zmiana nazwy formacji (25 kwietnia - 14 czerwca 1920 r.)}

Polska ofensywa na Ukrainie rozpoczęła się 25 kwietnia 1920 r. Jej celem miało być nie tylko wyparcie bolszewików z Ukrainy i pomoc Dyrektoriatowi URL w zbudowaniu silnej państwowości, ale również sprowokowanie przeciwnika do walnej bitwy. Mimo że większość swych sił bolszewicy rozmieścili na Białorusi, polskie dowództwo uważało, że podejmą oni próby odbicia Ukrainy dużymi siłami z powodów gospodarczych. Na drodze połączonym polsko-ukraińskim wojskom stały dwie armie bolszewickie 12 i 14, które liczyły łącznie ok. 16 tys. bagnetów i 4 tys. szabel ${ }^{33}$. Formacja płk. Udowyczenki miała się zmierzyć z oddziałami ostatniej z nich.

Od 26 kwietnia 1920 r. w polskich działaniach zaczepnych brał udział kureń wydzielony z IV Brygady w sile 450 bagnetów, 190 szabel, 12 karabinów maszynowych i 4 dział. Został on oddany pod dowództwo ppłk. Szandruka. Głównym celem jego działań miało być zajęcie do 27 kwietnia Mohylowa Podolskiego. Miasto było bronione przez dwa pułki ze 122 Brygady Strzelców (BS), liczące razem ok. 500 bagnetów. Oddziały bolszewickie na kierunku natarcia kurenia ppłk. Szandruka były jednak zdemoralizowane wieściami

31 Dok. Nr 241. Raport tygodniowy polityczny, b.m., 8 IV 1920 r. [w:] ibidem, s. 515.

32 Dok. Nr 195. Komunikat operacyjny nr 95, Tarnopol, 2 IV 1920 r. [w:] ibidem, s. 449; O. Udowyczenko, Tretja Zalizna..., s. 41-42; J. Legieć, Armia..., s. 68-69; A. Rukkas, $R a-$ zem..., s. 243.

${ }^{33}$ Ukrajinśko-moskowśka..., s. 3-4; O. Udowyczenko, Tretja Zalizna..., s. 42; J. Legieć, Armia..., s. 72-73. 
o polskiej ofensywie i działaniami partyzantów atamana Wasyla Balija. Dowództwo 122 BS już 25 kwietnia zarządziło ewakuację z Mohylowa, o czym Ukraińcy dowiedzieli się od jeńców schwytanych przez kawalerię. Przez prawie cały dzień 26 kwietnia kureń ppłk. Szandruka rzeczywiście nie napotkał oporu. Pierwsze i jedyne starcie z bolszewikami miało miejsce pod wsią Jaryszowce. Następnego dnia kawaleria ukraińska wkroczyła do Mohylowa Podolskiego bez walki. Podobnie jak w 1919 r., rumuńska artyleria znowu mylnie wzięła Ukraińców za bolszewików. Tym razem nikt nie odniósł obrażeń ${ }^{34}$.

W ciągu następnych dni okolice Mohylowa obsadziły oddziały 2 Dywizji, a w samym mieście ulokował się jej sztab. Kureń wydzielony do zdobycia miasta został ponownie wcielony do IV Brygady. W dalszych działaniach bojowych brała udział tylko kawaleria, podczas gdy pozostałe oddziały dywizji zajęły się tworzeniem instytucji wojskowych i administracji oraz przygotowaniami do mobilizacji ${ }^{35}$.

Kawaleria 2 Dywizji bez większych problemów zajęła 2 maja linię Jampol-Babczyńce i oczekiwała na nadejście Armii Czynnej URL gen. Omelianowycza-Pawłenki. 5 maja pierwsze oddziały ukraińskie, które brały udział w pochodzie zimowym, dotarły do linii frontu i zluzowały 2 Dywizję. 11 maja formacja płk. Udowyczenki została podporządkowana dowódcy Armii Czynnej URL, gen. Omelianowyczowi-Pawłence. W tym czasie znajdujące się pod jego dowództwem oddziały przygotowywały się do przeprowadzenia mobilizacji na wyzwolonym obszarze. Aby usprawnić werbunek, do Mohylowa Podolskiego sprowadzono II Brygadę Zapasową. Mobilizację do Armii Czynnej URL na terenie Podola ogłoszono 15 maja, przy czym 2 Dywizja prowadziła ją na terenie powiatu mohylowskiego. Rekrutacja obejmowała poborowych z roczników 1897-1899. Byli oni wpierw wcielani do brygady zapasowej, a następnie do oddziałów frontowych. Na terenie powiatu mohylowskiego udało się 2 Dywizji zmobilizować ok. 2 tys. rekrutów. Również 15 maja rozpoczęto formowanie VI Brygady. Poważnym problemem okazał się jednak brak odpowiedniej ilości uzbrojenia dla rekrutów ${ }^{36} .26$ maja stan

34 O. Udowyczenko, Tretja Zalizna..., s. 42; J. Legieć, Armia..., s. 80-82; M. Klimecki, Galicja Wschodnia 1920, Warszawa 2005, s. 71. Powyższe informacje warto porównać do raportu sytuacyjnego sztabu bolszewickiej 14 Armii, z którego można błędnie wywnioskować, że na całym froncie na Wołyniu i Podolu „czerwoni” skutecznie nacierali na pozycje Wojska Polskiego i udanie odpierali polskie i ukraińskie ataki: Dok. $n r$ 57. Sprawka-orientirowka sztaba 14-j Armii o pałażenii na frontie, b.m., 26 IV 1920 r. [w:] Grażdanskaja..., s. 66-67.

35 O. Udowyczenko, Tretja Zalizna..., s. 42-46; J. Ślipiec, Drogi..., s. 192; J. Legieć, Armia..., s. 82.

${ }^{36}$ Dok. Nr 612. [Rozkaz] do pułkownika Wojsk Ukrainskich Udowiczenki przez 6 Armie Wojska Polskiego, Warszawa, 2 V 1920 r. [w:] Bitwa o Ukrainę... s. 1069-1070; Dok. Nr 729. Utworzenie przy Naczelnym Dowództwie Komisji dla spraw ukrainskich, [Warszawa], 
żywieniowy dywizji (bez brygady zapasowej) wynosił 409 oficerów, 64 urzędników wojskowych, 1476 kozaków, 358 wierzchowców i 172 konie taborowe ${ }^{37}$.

29 maja 1920 r. z rozkazu Naczelnego Dowództwa Armii URL 2 DS przemianowano na 3 Żelazną Dywizję Strzelecką. Rozkaz ten wszedł jednak w życie dopiero 9 czerwca, gdy odczytano jego treść w dywizjach Armii Czynnej. W tym samym rozkazie zmieniono numerację jej brygad na VIIIX, a brygady zapasowej na III. Podporządkowano jej również 3 Zbiorczy Pułk Konny, w którym znajdowało się wielu doświadczonych weteranów pamiętających służbę w poprzedniej 3 Dywizji ${ }^{38}$. Decyzję dowództwa ukraińskiego na pewno motywowało kilka czynników. Pierwszym była właśnie duża liczba oficerów i kozaków, byłych „Żelaznych”, którzy znaleźli się w 2 Dywizji. Ostatnim mogła być chęć odtworzenia jednostki z powodów propagandowych - 3 Dywizja wsławiła się w walkach z bolszewikami i SZPR w 1919 r. W końcu Udowyczenko, awansowany w tym czasie na generała, był dowódcą tej popularnej wśród petlurowców formacji.

Od 23 maja 1920 r. bolszewicy zaczęli coraz silniej naciskać na odcinek Armii Czynnej URL. 2 czerwca formacja Udowyczenki otrzymała rozkaz zajęcia pozycji na froncie, gdzie została podporządkowana 12 DP płk. Mariana Januszajtisa. IV Brygada miała obsadzić rejon miejscowości Stina-Ignatówka, a V Brygada rejon Jałaniec-Tachtanówka. Pozostałe oddziały 2 Dywizji miały pozostać w Mohylowie. Pierwsze starcie z przeciwnikiem przypadło V Brygadzie. W walkach w nocy z 7 na 8 czerwca jednostka straciła 1 śmiertelnie rannego oficera, 2 zabitych i 18 rannych kozaków oraz 4 zaginionych ${ }^{39}$.

Na początku czerwca 1 Armia Konna Siemiona Budionnego przełamała front wojsk polskich. Nie mogąc zlikwidować wyłomu stworzonego przez bolszewików, siły sojuszników zostały zmuszone do odwrotu. 12 czerwca, siedem dni po przełamaniu polskich pozycji, 3 Dywizja liczyła na stanie

9 V 1920 r. [w:] ibidem, s. 1208; Dok. Nr 777. Rozkaz do Sztabu Generalnego, Winnica, [11] V 1920 r. [w:] ibidem, s. 1260; O. Udowyczenko, Tretja Zalizna..., s. 46-47; J. Legieć, Armia..., s. 96; M. Klimecki, Galicja..., s. 77; A. Rukkas, Razem..., s. 243.

37 Centralnyj Derżawnyj Archiw Wyszczych Orhaniw Włady i Uprawlinnja Ukrajiny w Kyjewi (dalej: CDAWOWUUK), fond 1075: Wijśkowe ministerstwo Ukrajinśkoji Narodnoji Respubliky (dalej: f. 1075), opys (dalej: op.) 2, sprawa (dalej: sp.) 381, Spys wijśkowych czastyn, sztabiw, ustanow i instytucij i ich suczasnyj skład, b.m. 26 V 1920 r., k. 23; A. Rukkas, Razem..., s. 243-244.

38 CDAWOWUUK, f. 1078: Hołowne uprawlinnja Heneralnoho sztabu UNR, op. 4, sp. 2, Nakaz Hołownoji Komandy Wijśka Ukrajinśkoji Narodnoji Respubłiky cz. 35, b.m. 29 V 1920 r., k. 43; Dok. Nr 71. Nakaz Hołownoji Uprawy Wijśka UNR. 29 trawnia 1920 r., b.m., 29 V 1920 r. [w:] Ukrajinśko-moskowśka..., s. 31; O. Udowyczenko, Tretja Zalizna..., s. 50; Z. Karpus, Wschodni..., s. 27; A. Rukkas, Razem..., s. 244.

${ }^{39}$ Dok. Nr 66. Operatywnyj zwit z dnia 7 czerwnia do 24 hodyny, Dżyhówka, 8 VI 1920 r. [w:] Ukrajinśko-moskowśka..., s. 29; O. Udowyczenko, Tretja Zalizna..., s. 47; A. Rukkas, Razem..., s. 244. 
żywieniowym 795 oficerów i 3465 kozaków. Formacja była uzbrojona w 80 karabinów maszynowych i 9 dział ${ }^{40}$. Tego samego dnia dywizja otrzymała rozkaz wycofania się na linię Jampol-Rusawa-Tomaszpol. W trakcie odwrotu w dniach 12-14 czerwca VII Brygada straciła 1 zabitego i 1 rannego kozaka, a VIII Brygada 1 zabitego i 2 zaginionych kozaków ${ }^{41}$.

\section{3 Żelazna Dywizja Strzelecka w kampanii obronnej na Podolu i w Galicji Wschodniej (15 czerwca - 17 września 1920 r.)}

13 czerwca 1920 r. NDWP wydało wojskom polskim i ukraińskim rozkaz odwrotu na linię Jaruga-Bielany-Grabowce-Bar-Deraźnia-Letyczew-Lubar do dnia 16 czerwca $^{42}$. Zgodnie z nim 3 Żelazna DS zajęła pozycje na linii Wołodyjowce-Kalitynka (ok. 7,5 km). W dniach 17-18 czerwca bolszewicy przeprowadzili kilka silnych ataków na pozycje VII Brygady, które zostały odparte. Rannych zostało 2 oficerów i 5 kozaków. 19 czerwca, dzięki biernej postawie bolszewików, 3 Żelazna DS bez przeszkód wycofała się na linię Bielany-Łozowa-chutor Wyszkowski ${ }^{43}$.

Zmiana charakteru walk oraz taktyki stosowanej przez przeciwnika skłoniła ukraińskie dowództwo do przeszkolenia piechoty w zakresie odpierania ataków kawalerii. 19 czerwca 1920 r. gen. Omelianowycz-Pawłenko wydał rozkaz, w którym nakazano przeprowadzić pozorowany atak jazdy na piechotę z odległości „500 kroków”. Każdy z kozaków miał policzyć, ile zdąży oddać strzałów do momentu, gdy kawalerzyści dojadą do pozycji piechurów. Rozkaz miał być wprowadzony w życie w każdej dywizji. Jego celem było nie tylko wypracowanie skutecznej taktyki odpierania ataku kawalerii bolszewickiej, ale również zniwelowanie zgubnego wpływu szarż na morale piechoty ${ }^{44}$. W tym czasie nawet liczny oddział strzelców mógł rzucić się do ucieczki na widok atakującej kawalerii przeciwnika. Dodatkowo na strach wśród piechoty wpływała zła sława konnicy bolszewickiej ${ }^{45}$.

${ }^{40}$ Dok. Nr 84. Widomost' pro skład Armij Ukrainśkoji N. P. na 12 czerwnia 1920 r., b.m., 12 VI 1920 r. [w:] Ukrajinśko-moskowśka..., s. 36.

${ }^{41}$ O. Udowyczenko, Tretja Zalizna..., s. 50.

42 Dok. Nr 90. Tajemno Nakaz Wijśkam Dijewoji Armij U. N. R. cz. 0104, Babczyńce, 15 VI 1920 r. [w:] Ukrajinśko-moskowśka..., s. 39.

43 O. Udowyczenko, Tretja Zalizna..., s. 50-52.

44 Dok. Nr 103. Nakaz Wijśkam Dijewoji Armij U. N. R. cz. 0109, Ozaryńce, 19 VI 1920 r. [w:] Ukrajinśko-moskowśka..., s. 45.

45 Największy wpływ na wykreowanie złej sławy kawalerii Armii Czerwonej miał jej skład osobowy, szczególnie w przypadku 1 Armii Konnej i III Korpusu Hajka Bżyszkina 
W dniu 22 czerwca 1920 r. Ukraińcy uderzyli na pozycje przeciwnika, aby wprowadzić zamieszanie w jego szeregach i tym samym przejąć inicjatywę na tym odcinku frontu. W wyniku walk VIII Brygada straciła 2 rannych kozaków i 1 oficera wziętego do niewoli. Następnego dnia 3 Żelazna DS przeszła do kolejnego kontrataku. W jego trakcie VII Brygada rozbiła 369 Pułk Strzelecki (p. strz.) ze składu 123 BS, zdobywając 2 działa, 10 karabinów maszynowych i wielu jeńców ${ }^{46}$. Straty formacji gen. Udowyczenki wyniosły 3 rannych oficerów, 1 zabitego i 5 rannych kozaków ${ }^{47}$. Duży sukces odniesiony tego dnia znalazł swe odbicie w pochwale od gen. Omelianowycza-Pawłenki dla dowódców dywizji i VII Brygady ${ }^{48}$.

25 czerwca 1920 r. 3 Żelazna DS i 4 Kijowska DS przełamały front pod Bielanami i zmusiły przeciwnika do wycofania się ${ }^{49}$. Ukraińcy nie ścigali jednak przeciwnika i utrzymywali dotychczasowe pozycje. W ciągu następnych czterech dni na froncie formacji gen. Udowyczenki miały miejsce głównie wymiany ognia karabinowego oraz artyleryjskiego, w wyniku których poległo 3 oficerów i 8 kozaków, a rany odniosło kolejnych 5 oficerów i 27 kozaków. 29 czerwca 3 Żelazna Dywizja otrzymała rozkaz przejęcia części pozycji polskiej XXIV BP z 12 DP i zniszczenia torów kolejowych między wsiami Stepanki i Mytki. Jako wsparcie dla ukraińskiej dywizji Polacy przydzielili trzy baterie dział i 54 pp z $12 \mathrm{DP}^{50}$.

(znanego jako Gaj-Chan). Kawalerzyści bardzo często pastwili się nad jeńcami, a nawet mordowali ich. Byli niejednokrotnie bezlitośni również wobec ludności cywilnej, która padała ofiarą gwałtów, grabieży i morderstw ze strony czerwonej konnicy. Zob. m.in. opis zbrodni na jeńcach wojennych: I. Babel, Dziennik 1920, Warszawa 1990, s. 145-147.

46 Spora część raportów obu walczących stron zawierała przeważnie zawyżone i zaokrąglone dane dotyczące strat przeciwnika. W niektórych wypadkach podawano jednak bardzo dokładne liczby dotyczące zabitych i wziętych do niewoli wrogów oraz zdobytego na nich sprzętu i koni. W tekście głównym podane zostały liczby i informacje pojawiające się w raportach, ale należy mieć na uwadze, że wiele z nich z pewnością było zawyżonych i wyolbrzymionych.

${ }^{47}$ M. Kukiel, Moja wojaczka na Ukrainie - wiosna 1920: dziennik oficera sztabu generalnego, wstęp i oprac. J. Zuziak, Warszawa 1995, s. 64; O. Udowyczenko, Tretja Zalizna..., s. 52-53; J. Legieć, Armia..., s. 109.

${ }^{48}$ Dok. Nr 114. Komandirowi 3 Zaliznoji dywizii henerał-chorunżomu Udowyczenku cz. 133/b, Ozaryńce, 23 VI 1920 r. [w:] Ukrajinśko-moskowśka..., s. 51.

49 Dok. Nr 122. Komdiwam 1 Zaporirzśkoji, 2 Wołynśkoji, 3 striłećkoji, 4 Kyjiwśkoji, 5 Chersonśkoji i 3 kinnomu połku cz. 518, Ozaryńce, 25 VI 1920 r. [w:] ibidem, s. 54; Dok. Nr 124. Operatywnyj zwit Sztabu Armij UNR 25 czerwnia 1920 r., b.m., 25 VI 1920 r. [w:] ibidem, s. 56.

${ }^{50}$ Dok. Nr 140. Nakaz po wijśkam dijewoji armij U. N. R. cz. 0119, Ozaryńce, 29 VI 1920 r. [w:] ibidem, s. 63-65; O. Udowyczenko, Tretja Zalizna..., s. 54-55; J. Legieć, Armia..., s. 110. 
Następnego dnia Ukraińcy rozpoczęli obsadzanie wyznaczonych pozycji $^{51}$. Pułkownik Marian Kukiel w ten sposób opisał luzowanie swej brygady:

„Od nocy są na skrzydle prawem Dońcy Frołowa, w południe nadciąga brygada VII dywizji 3 żelaznej. Spotkanie z nimi i zapoznanie wzajemne. Ciekawe luzowanie. Idą wzdłuz frontu, rozkładają się na kwaterach, wystawiają słabe forpoczty, a jednocześnie ich dywizja zaporowa wali na tyły przeciwnika i zwija mu front. [...] Podoba mi się ich zdolność manewrowania i wspaniały instynkt wojenny. [...] Dalej III Dywizja Brygadą VII sięga po Matejkowo, obejmując odcinek 53 pułku piechoty, cały czy też część, objąć ma jutro Brygada IX tejże dywizji" ${ }^{2}$.

Od 1 lipca 1920 r. front 3 Żelaznej DS ciągnął się od Halczyniec do Baru. Następnego dnia bolszewicy przypuścili atak na lewe skrzydło „żelaznych”, został on jednak odparty przy stracie 1 zabitego i 11 zaginionych kozaków. Kontratak 3 Dywizji zsynchronizowany z atakiem dywizji 4 Kijowskiej i 1 Zaporoskiej zmusił przeciwnika do oddania zajętych wcześniej wsi Stepanki, Goraj, Karyszków i Grabowce ${ }^{53}$.

4 lipca sztab 6 Armii zdecydował o przekazaniu zwierzchnictwa nad 3 Dywizją dowódcy Armii Czynnej URL. Komunikat zawierał również pochwały od płk. Januszajtisa za dotychczasową postawę dywizji na froncie ${ }^{54}$. Następnego dnia wobec przerwania przez bolszewików frontu 6 Armii i odwrotu tej ostatniej gen. Omelienowycz-Pawłenko wydał rozkaz o wycofaniu

${ }^{51}$ Nowy dowódca 6 Armii, gen. Jan Romer, tłumaczył zmiany w obsadzie pozycji tym, że chciał stworzyć rezerwy z oddziałów, które zostały ściągnięte z linii frontu: „Natychmiast udałem się do biur sztabu i dowiedziałem się, że i w Lubarze są już bolszewicy, stwierdziłem, że wszystkie siły VI Armii są zupełnie jednostajnie rozrzucone wzdłuż frontu i że armia nie ma żadnych rezerw. [...] Mój plan był następujący: skłonić Ukraińców do zajęcia frontu aż po Bar i ażeby ich do tego zachęcić, oddałem im do dyspozycji 3. Dywizję gen. Udowiczenki, czynnej dotąd w obrębie, VI Armii i odbyłem konferencję z atamanem Petlurą. Dobre stosunki, które już nawiązałem jako dowódca etapów na Ukrainie z Ukraińcami, tak proste (a dotąd niedokonane) oddanie dyw. Udowiczenki pod rozkazy gen. Pawłenki, przyniosły rychłe owoce. To, o co się gen. Iwaszkiewicz na próżno przez miesiące starał, to ja osiągnąłem w ciągu jednego dnia. 30 czerwca Ukraińcy objęli odcinek do Baru, ponadto główny ataman Petlura sam pojechał na front, żeby przeprowadzić rozmaite operacje zaczepne, odciążające nas itd.”. Zob. J. Romer, Pamiętniki, Warszawa 2011, s. 344-345.

52 M. Kukiel, Moja..., s. 67.

${ }_{53}$ Dok. Nr 150. Operatywnyj zwit za 2 łypnia do 20 hodyn cz. 652, b.m., 2 VII 1920 r. [w:] Ukrajinśko-moskowśka..., s. 69-70; O. Udowyczenko, Tretja Zalizna..., s. 55.

${ }_{54}$ Dok. Nr 160. Nakaz wijśkam dijewoji armij U. N. R. cz. 0125, Górny Olczedajów, 4 VII 1920 r. [w:] Ukrajinśko-moskowśka..., s. 74; O. Udowyczenko, Tretja Zalizna..., s. 56; J. Romer, Pamiętniki..., s. 345; A. Rukkas, Razem..., s. 244. 
Armii Czynnej URL na nowe pozycje. Przestrzegł on również dowódców swych dywizji o możliwych atakach kawalerii przeciwnika i zalecił wykonanie rozkazu nocą. 3 Żelazna DS miała obsadzić miasteczko Jełtuszków i wieś Hodaki (linia frontu miała długość ok. $11 \mathrm{~km})^{55}$. Kawaleria dywizyjna, szczególnie sotnie VII, VIII i IX Brygady, była w tym czasie wykorzystywana do organizowania krótkich wypadów na tyły wrogich jednostek. Celem tych akcji, poza zadaniem strat i zdezorganizowaniem zaplecza przeciwnika, było również zmuszenie „czerwonych” do przyjęcia bardziej defensywnej postawy, co z kolei miało umożliwić spokojny odwrót 3 Żelaznej DS na nowe pozycje ${ }^{56}$.

Do 9 lipca oddziały ukraińskie zmieniały swoje pozycje i stopniowo wycofywały się na zachód, ale okazało się, że konieczny jest odwrót za Zbrucz ${ }^{57}$. 12 lipca 3 Dywizja i pozostałe oddziały Armii Czynnej URL przeszły przez rzekę $\mathrm{w}$ trzech punktach. Przeprawy zostały potem zniszczone, by utrudnić przeciwnikowi przeprawę i kontynuowanie ofensywy ${ }^{58}$. W tym dniu dywizja gen. Udowyczenki liczyła w stanie bojowym 225 oficerów, 751 bagnetów, 381 szabel, 12 dział i 66 sprawnych karabinów maszynowych ${ }^{59}$.

14 lipca 1920 r. 3 Dywizja zajęła pozycje od wsi Zbrzyź do Husiatynia (linia frontu ok. $27 \mathrm{~km}$ ), na zachodnim brzegu Zbrucza. Jako wsparcie przydzielono jej pociąg pancerny „Karmeluk” oraz ponownie 54 pp i dwie polskie baterie artylerii. Tego dnia bolszewicy podjęli próbę zdobycia przyczółka pod Husiatyniem, która zakończyła się ich klęską i dużymi stratami. Ukraińcy stracili 1 zabitego i 4 rannych $^{60} .15$ lipca bolszewicy kolejny raz próbowali wywalczyć przyczółek na zachodnim brzegu Zbrucza. Pod wsią Huków wylądowała część 366 p. strz. w sile 200 bagnetów, która następnie nacierała na zachód. Udany kontratak 3 Żelaznej DS doprowadził jednak do rozbicia

${ }_{55}$ Dok. Nr 164. Nakaz po wijśkam dijewoji armij UNR. cz. 0127, Górny Olczedajów, 5 VII 1920 r. [w:] Ukrajinśko-moskowśka..., s. 75-77.

${ }_{56}$ B. Skrobacz, Kawałerija zbrojnych sył UNR u polśko-radjanśkij wijni 1920 r. ta osobływosti jiji zastosuwannja w oboronnych bojach i kontrnastupi (traweń-żowteń 1920 r.), „Wijśkowo-naukowyj żurnał” 2008, nr 10, s. 181.

57 O. Udowyczenko, Tretja Zalizna..., s. 57-59.

58 Dok. Nr 183. Operatywnyj zwit za 12 łypnia cz. 731, Borszczów, 12 VII 1920 r.; Dok. Nr 184. Operatywnyj zwit za 13 łypnia cz. 733, b.m., 13 VII 1920 r. [w:] Ukrajinśko-moskowśka..., s. 92; O. Udowyczenko, Tretja Zalizna..., s. 60-61.

59 Dok. Nr 186. Widomost' pro bojowyj stan Dijewoji Armij na 12 łypnia 1920 r., b.m., 12 VII 1920 r. [w:] Ukrajinśko-moskowśka..., s. 93.

${ }^{60}$ Dok. Nr 187. Nakaz Wijśkam Dijewoji Armij UNR cz. 0135, Borszczów, 14 VII 1920 r. [w:] ibidem, s. 95; Dok. Nr 191. Operatywnyj zwit Sztadarmu UNR do 10 hod. 14 typnia cz. 735, b.m., 14 VII 1920 r. [w:] ibidem, s. 97; O. Udowyczenko, Tretja Zalizna..., s. 61-62. W jednym z bolszewickich raportów podano nieprawdziwą informację o zajęciu Husiatynia przez Armię Czerwoną: Dok nr 275. Iz tełegrafnago bjulletienia Ukrosta o nastuplienii na Juga-Zapadnom Frontie, b.m., 14 VII 1920 r. [w:] Grażdanskaja..., s. 276. 
bolszewików, którzy zostawili na „ukraińskim” brzegu 20 zabitych i 15 wziętych do niewoli. Straty Ukraińców znowu wyniosły 1 zabitego i 4 rannych. Do końca dnia wskutek wymiany ognia straty wzrosły o 2 zabitych oficerów i 4 kozaków oraz 1 rannego oficera i 7 kozaków ${ }^{61}$.

W dniach 16-19 lipca 1920 r. na froncie Dywizji nie dochodziło do większych starć. Położone nad brzegiem Zbrucza wsie przechodziły w walce z rąk do rąk, wydarzenia te nie wpływały jednak znacząco na rozwój sytuacji na całym froncie. Wywiad ukraiński stwierdził jednak koncentrację sił bolszewickich $^{62}$. 19 lipca wyznaczono 3 Żelaznej DS nowe pozycje na linii Polejów-Janów-Wiśniowczyk-Podhajce. Jej sąsiadami były na południu 4 Kijowska DS, a na północy $12 \mathrm{DP}^{63}$. Rankiem tego dnia oddział bolszewicki w sile ok. 200 bagnetów i 400-450 szabel przebił się przez linię frontu pod wsią Szydłowiec. Miejscowość ta leżała na styku pozycji polskich i ukraińskich. Kawaleria bolszewicka zajęła również miejscowości Sidorów i Krzyweńkie. Popołudniu do kontrataku ruszyła IX Brygada będąca dotychczas w rezerwie. Do wieczora wyparła ona przeciwnika z Szydłowca. W wyniku starcia poległo 40 bolszewików, a 3 zostało wziętych do niewoli. Straty ukraińskie wyniosły w zabitych i rannych 5 oficerów oraz 24 kozaków. Zaginęło również 20 kozaków ${ }^{64}$.

20 lipca 1920 r. bolszewicy, w sile ok. 400 bagnetów i 400 szabel, ponownie uderzyli na Szydłowiec. Po zajęciu tej miejscowości rozpoczęli atak w kierunku Sidorowa. Mimo odparcia szarż wrogiej kawalerii Ukraińcy zostali zmuszeni do opuszczenia wioski. Sidorów został jeszcze tego samego dnia odzyskany dzięki sprawnie przeprowadzonym kontratakom, które zmusiły bolszewików do odwrotu. Generał Udowyczenko wysłał za uchodzącym przeciwnikiem kawalerię dywizyjną. Bolszewicy stracili tego dnia 75 zabitych, większość z nich straciła życie w wyniku szarży ukraińskiej konnicy. Do niewoli trafiło 3 żołnierzy wroga. Straty ukraińskie wyniosły w zabitych zaledwie 3 oficerów i 8 kozaków ${ }^{65}$.

${ }^{61}$ Dok. Nr 194. Operatywnyj zwit do 9 hodyny 15 łypnia cz. 753, b.m., 15 VII 1920 r. [w:] Ukrajinśko-moskowśka..., s. 98; O. Udowyczenko, Tretja Zalizna..., s. 62.

62 Dok. Nr 197a. Rozwidocznyj zwit Sztabu Armij UNR henerała Pawłenka do 16 hod. 17.7.1920 cz. 93/r., b.m., 17 VII 1920 r. [w:] Ukrajinśko-moskowśka..., s. 99; O. Udowyczenko, Tretja Zalizna..., s. 62-63.

${ }^{63}$ Dok. Nr 204. Nakaz Wijśkam Dijewoji armij U. N. R. cz. 0137, Borszczów, 19 VII 1920 r. [w:] Ukrajinśko-moskowśka..., s. 103-104.

64 Dok. Nr 205. Operatywnyj zwit do 18 hodyn 19 łypnia cz. 783, b.m., 19 VII 1920 r. [w:] ibidem, s. 104; Dok. Nr 208. Operatywnyj zwit za 19 łypnia do 8. hod. 20 łypnia cz. 0791, Borszczów, 20 VII 1920 r. [w:] ibidem, s. 105; O. Udowyczenko, Tretja Zalizna..., s. 64; J. Ślipiec, Drogi..., s. 201.

${ }^{65}$ Dok. Nr 211. Operatywnyj zwit do 8 hodyn 21 łypnia cz. 800, Borszczów, 21 VII 1920 [w:] Ukrajinśko-moskowśka..., s. 106-107; J. Ślipiec, Drogi..., s. 201. 
W dniach 21-22 lipca wywiad ukraiński doniósł o sile, jaką dysponuje przeciwnik w Szydłowcu i okolicach. Stacjonowały tam 367 (200 bagnetów, 10 szabel, 9 KM, 2 działa); 368 (125 bagnetów, 19 szabel, 9 karabinów maszynowych, 2 działa) i 369 Pułk Strzelecki (150 bagnetów, 26 szabel, 10 KM, 2 działa) należące do 123 BS oraz 115 Pułku Kawalerii (pk) w sile ok. 250 szabel. Koncentracja sił oznaczała przygotowania bolszewików do kolejnego ataku. Liczebnie nie dorównywali oni 3 Żelaznej DS, która w tym czasie miała w stanie bojowym ok. 1300 bagnetów i szabel. Ukraińcy nie mieli jednak tak licznych rezerw jak przeciwnik i w wypadku poniesienia dużych strat mieliby trudności z uzupełnieniem szeregów ${ }^{66}$.

22 lipca 1920 r. bolszewicy chwilowo zajęli Sidorów, po czym zostali z niego wyparci przez VII Brygadę. Rany w boju odniosło dwóch ukraińskich oficerów. Następnego dnia Armia Czerwona przełamała front polsko-ukraiński w kilku miejscach i zajęła Husiatyń. 24 lipca 3 DS brała udział w ciężkich walkach o Sidorów. Wieś przechodziła z rąk do rąk. W końcu bolszewicy wyparli z niej Ukraińców ${ }^{67}$. „Czerwoni” planowali kontynuowanie natarcia i wysłali piechotę na Tłusteńkie. W ukraińskim komunikacie operacyjnym opisano atak bolszewicki i jego odparcie: „Gęste tyraliery wroga podpuszczono blisko do naszych stanowisk na wschód od Tłusteńkie, a po zbliżeniu się nieprzyjaciela na odległość 100 kroków otworzono do niego ogień, który spowodował u nieprzyjaciela duże straty w zabitych. Nieprzyjaciel w panice zaczął uciekać pozostawiając na polu bitwy wielu zabitych i rannych. W tym samym czasie, kiedy piechota nieprzyjaciela prowadziła natarcie na Tłusteńkie, część naszej konnej dywizji umiejętnym manewrem wyszła na tyły nieprzyjaciela od strony Wasylkowa, odcięła mu odwrót biorąc do niewoli 150 ludzi [liczba prawdopodobnie przesadzona - M. K.]. Uciekających komunistów porąbano na miejscu" 68 .

Jeszcze tego samego dnia opracowano plan kontrataku, którego celem było odbicie Sidorowa i Husiatynia. W rejonie ostatniej z miejscowości miał stacjonować wrogi oddział, którego stan bojowy sięgał ok. 300-500 bagnetów

${ }^{66}$ Dok. Nr 212. Rozwidocznyj zwit Sztabu Armij UNR. do 14 hodyn 21. VII. 20 r. cz. 100/r, b.m., 21 VII 1920 r. [w:] Ukrajinśko-moskowśka..., s. 107; Dok. Nr 215. Rozwidocznyj zwit Sztabu Armij UNR. do 16 hodyn 22. VII. 920. cz. 102/r, b.m., 22 VII 1920 r. [w:] ibidem, s. 108 .

67 Dok. Nr 222. Operatywnyj zwit za 24 Eypnia do 19 hod. Cz. 0836, Jezierzany, 24 VII 1920 r. [w:] ibidem, s. 110; Dok. Nr 61. Rozkaz do Wojsk Armii Czynnej URL, 25 VII 1920 r. [w:] Bitwa lwowska..., t. I, s. 148; O. Udowyczenko, Tretja Zalizna..., s. 65; P. Szandruk, Siła..., s. 109; J. Legieć, Armia..., s. 120.

68 Dok. Nr 228. Operatywnyj zwit za 25 łypnia do 18 hod. Cz. 0842, Jezierzany, 25 VII 1920 r. [w:] Ukrajinśko-moskowśka..., s. 113; Dok. Nr 64. Komunikat operacyjny do godz. 18 [dn.] 25 VII [1920 R.], 25 VII 1920 r. [w:] Bitwa lwowska..., t. I, s. 152. 
i 250-300 szabel, nieustaloną liczbę taczanek z karabinami maszynowymi ${ }^{69}$ oraz 3 działa polowe. Pod Husiatyń wysłano większą część konnicy dywizyjnej oraz Samodzielną Dywizję Kawalerii (SDK), a piechota 3 Dywizji miała za zadanie odbić Sidorów. Walki o wieś znowu toczyły się ze zmiennym szczęściem. Wieczorem, po godz. 16:00 część bolszewickiego 115 pk, w sile ok. 250 szabel, uderzyła na VII Brygadę od strony wsi Zielona. W trudnej sytuacji znalazł się 20 kureń z tejże formacji. Został on zaatakowany z zaskoczenia i okrążony przez wrogą kawalerię. W ciężkiej walce poległo lub zostało zamordowanych 14 ukraińskich oficerów i 24 kozaków. Pozostali, w większości ranni, zostali wzięci do niewoli. Ze spóźnioną odsieczą 20 kureniowi ruszyła kawaleria dywizyjna. Tym razem fortuna była po stronie Ukraińców. W starciu rozbili oni 115 pk. Wśród 28 poległych bolszewików znaleźli się dowódcy pułku oraz jednego ze szwadronów. Ponadto ukraińscy kawalerzyści zdobyli 7 zdrowych koni oraz 9 siodeł. Wieczorem Husiatyń został odbity przez SDK, a wieś Czabarówka przez polską piechotę. Choć bolszewicy zostali pobici i stracili chwilowo wolę walki, to jednak utrzymali część pozycji na zachód od Sidorowa ${ }^{70}$.

25 lipca 1920 r. dowódca Armii Czynnej URL rozkazał 3 Żelaznej DS i SDK zlikwidowanie wrogiego przyczółka na zachodnim brzegu Zbrucza. Przeciwnik uprzedził jednak natarcie ukraińskie swym atakiem z rejonu Sidorowa, Suchodołu i Wasylkowa na wsie Krzyweńkie i Tłusteńkie. Atak ten został poprzedzony ostrzałem artyleryjskim, a następnie do szarży ruszyła kawaleria, w sile ok. 1,8-2 tys. szabel. Działania jazdy bolszewickiej skutecznie powstrzymały piechota i artyleria ukraińska. Bolszewików udało się zdezorganizować i rozproszyć. Wtedy uderzyła na nich kawaleria 3 Żelaznej DS i SDK (ok. 1,5-1,7 tys. szabel), zadając przeciwnikowi duże straty i zmuszając go do wycofania się za Zbrucz. Do niewoli wzięto 150 bolszewików, liczba

69 Taczanka - dwuosiowy pojazd konny, uzbrojony w karabin maszynowy (montowany z tyłu pojazdu i strzelający w tym kierunku), z którego można było prowadzić bezpośredni ogień w czasie postoju i jazdy (mniej celny). W trakcie wojny polsko-bolszewickiej improwizowany (przerabiano różne typy wozów i bryczek), po wojnie standaryzowane, np. polskie taczanki wz. 36 .

70 Dok. Nr 227. Operatywnyj zwit do 8 hodyn 25 łypnia cz. 837, Jezierzany, 25 VII 1920 r. [w:] Ukrajinśko-moskowśka..., s. 113; Dok. Nr 61. Rozkaz do Wojsk Armii Czynej URL, 25 VII 1920 r., [w:] Bitwa lwowska..., t. I, s. 148; Dok. Nr 63. Komunikat operacyjny do godz. 8 [dn.] 25 VII [1920 R.], 25 VII 1920 r. [w:] ibidem, s. 150-151; P. Szandruk, Siła..., s. 109; J. Legieć, Armia..., s. 120. W innym komunikacie jest podana liczba 18 oficerów i 23 kozaków poległych z 20 Kurenia; zob. Dok. Nr 228. Operatywnyj zwit za 25 łypnia do 18 hod. 25 VII 1920 r., [w:] Ukrajinśko-moskowśka..., s. 114; Dok. Nr 64. Komunikat operacyjny do godz. 18 [dn.] 25 VII [1920 R.], 25 VII 1920 r. [w:] Bitwa lwowska..., t. I, s. 152. 
poległych była podobna, a znaleźli się wśród nich dowódcy i politrucy ${ }^{71}$. Straty ukraińskie były niewielkie ${ }^{72}$.

Tego samego dnia Kwatermistrz Generalny Armii URL płk Mykoła Kapustianski starał się uzgodnić z polskim dowództwem kilka bardzo ważnych kwestii dotyczących funkcjonowania wojsk ukraińskich w Galicji Wschodniej. Otóż dotychczas oddziały ukraińskie mogły stacjonować jedynie na wschód od Seretu. Na zachód od tej rzeki formacje Armii URL mogły przebywać jedynie... w obozie w Łańcucie. Ten stan rzeczy uniemożliwiał rozlokowanie brygad zapasowych dywizji ukraińskich w pobliżu frontu i tym samym skuteczne ich uzupełnianie w wypadku poniesionych strat. Podporucznik Albert Bzowiecki, polski oficer łącznikowy przy Dowództwie Armii Czynnej URL, donosił: „Chodzi tu o brygady zap.[asowe], które są de facto słabymi baonami, ale stanowią rezerwę armii czynnej; która ponadto ma tę moralną pewność, że za nimi ktoś stoi. Wyciągnięcie tych brygad do Łańcuta odcięłoby dywizje [ukraińskie] od wszelkich uzupełnień; przebywanie zaś na wschód od Seretu - jak twierdzi płk Kapustianski, nie zawsze jest ze względów operacyjnych możliwe"73. Ponadto oficer łącznikowy zwrócił uwagę na finansowy aspekt przebywania Armii Czynnej URL na polskim terytorium: „Ukraińcy mają tylko karbowańce, których nikt brać nie chce" 74 .

Mimo zwycięstwa w kilkudniowych zmaganiach pod Sidorowem i nad Zbruczem, 26 lipca Ukraińcy zostali zmuszeni do wycofania za Seret. Decyzja ta była podyktowana trudną sytuacją, w jakiej znalazła się polska 6 Armia, na której odcinku doszło do przełamania frontu. 3 Dywizja miała obsadzić rejon Dżuryna. W trakcie wymarszu zaatakowali ją bolszewicy, którzy mieli nadzieję za zatrzymanie jej i zniszczenie. Ich atak zakończył się jednak dotkliwą porażką. W wyniku starcia pod wsią Tłusteńkie poległo ok. 50 bolszewików, a 120 innych dostało się do niewoli. Ukraińcy zdobyli ponadto 8 karabinów

${ }_{71}$ Ros. политический руководитель - kierownik polityczny. Była to osoba odpowiedzialna za pracę polityczną w danej jednostce oraz kontrolę nad „dowódcami”, w tym poprzez podpisywanie rozkazów (bez podpisu politruka rozkaz nie był ważny) lub ich wetowanie.

72 Dok. Nr 226. Nakaz Wijśkam Dijewoji Armii cz. 0141, Probużna, 25 VII 1920 r. [w:] Ukrajinśko-moskowśka..., s. 112; Dok. Nr 228. Operatywnyj zwit za 25 łypnia do 18 hod. cz. 0842, Jezierzany, 25 VII 1920 r., [w:] ibidem, s. 113-114; Dok. Nr 62. Rozkaz do wojsk Armii Czynnej URL, 25 VII 1920 r. [w:] Bitwa lwowska..., t. I, s. 149; O. Udowyczenko, Tretja Zalizna..., s. 66-68; P. Szandruk, Siła..., s. 109; J. Legieć, Armia..., s. 121.

73 Dok. Nr 59, Sytuacja Armii Ukraińskiej, 25 VII 1920 r. [w:] Bitwa lwowska..., t. I, s. 147. W tym czasie stan żywieniowy III Brygady Zapasowej wynosił 390 oficerów i kozaków oraz 26 koni. Stacjonowała w Buczaczu i okolicach: ibidem, s. 146.

74 Ibidem, s. 147. 
maszynowych i 60 koni. 27 lipca nie niepokojona 3 Żelazna DS wycofała się za Seret i pozostała w odwodzie Armii Czynnej URL ${ }^{75}$.

Pod koniec lipca stan żywieniowy formacji gen. Udowyczenki wynosił w przybliżeniu ok. 830 oficerów, 3,2 tys. kozaków i 700 koni ${ }^{76}$. Potrzebowali oni wypoczynku po ciężkich walkach oraz uzupełnienia poniesionych strat. Przez najbliższych kilka dni dywizja nie brała udziału w walkach poza jednym wyjątkiem. 30 lipca otrzymała rozkaz przesunięcia swej kawalerii w rejon Laskowic, aby osłonić prawe skrzydło 12 DP do czasu wyparcia na jej odcinku bolszewików za Seret ${ }^{77}$.

W tym czasie rejon stacjonowania „Żelaznych”, czyli powiat czortkowski, opanował chaos. Jak donoszono w raporcie sytuacyjnym Powiatowej Komendy Policji Państwowej w Czortkowie:

„Sytuacja w powiecie czortkowskim od kilku dni naprężona. Ruch uchodźczy ze wschodu olbrzymi. [...] Poszczególne formacje etapowe[,] tabory i luźne oddziały przeciągają przez powiat i miast[a] szerząc popłoch i rozsiewając najnieprawdopodobniejsze i fałszywe pogłoski. Watahy uzbrojonych dezerterów kryją się po lasach okolicznych, rabując i kradnąc środki żywności oraz niszcząc zasiewy po polach. Komenda etapu i żandarmeria polowa dotychczas w powiecie tut.[ejszym] służby pełnić nie zaczęły. Każda grupka żołnierzy, a nawet pojedyncze osoby wojskowe, jak donoszą poszkodowani, rekwirują bezprawnie podwody, pasze dla koni i środki żywności bez zapłaty i pokwitowania. [...] Naczelnicy gmin stracili wszelką władzę i są bezradni. Ceny środków żywności poszły o 100\% w górę, przejeżdżający uchodźcy wykupili wszystką żywność. [...] Powracające formacje wojskowe prowadzą ze sobą zadziwiającą ilość wozów, bryczek, pojazdów,

${ }^{75}$ Dok. Nr 230. Nakaz Wijśkam Dijewoji Armii U. N. R. cz. 0142, Jezierzany, 26 VII 1920 r. [w:] Ukrajinśko-moskowśka..., s. 114-116; Dok. Nr 107. Rozkaz do wojska Armii Czynnej URL, 26 VII 1920 r. [w:] Bitwa lwowska..., t. I, s. 211-213; Dok nr 324. Dwuchniedielnaja razwiedywatelnaja swodka sztaba Juga-Zapadnago Fronta o razmieszczienii sił $i$ bojewych diejstwiach pratiwnika na 1 awgusta 1920, b.m., 2 VIII 1920 r. [w:] Grażdanskaja..., s. 327; O. Udowyczenko, Tretja Zalizna..., s. 68-69; J. Legieć, Armia..., s. 121-122. Wysłanie 3 Dywizji do rezerwy było planowane już na noc z 25 na 26 lipca. Jej pozycje miała zająć 1 Dywizja Zaporoska. Żelazna DS miała przejść wtedy w rejon Czarnokońce Małe i Czarnokońce Wielkie. Do ostatniej z wymienionych wsi miał zostać wysłany sztab dywizji. Ostatecznie działania wojenne uniemożliwiły wykonanie tego rozkazu; zob. Dok. $\mathrm{Nr} 61$. Rozkaz do Wojsk Armii Czynnej URL, 25 VII 1920 r. [w:] Bitwa lwowska..., t. I, s. 148.

76 Dok. Nr 240. Sytuacja materialna 5-dniowa $z$ dn. 25 VII 1920 r., 29 VII 1920 r. [w:] ibidem, s. 455.

77 Dok. Nr 287. Komunikat operacyjny do godz. 20 [dn.] 30 VII 1920 r., 30 VII 1920 r. [w:] ibidem, s. 529; Dok. Nr 288. Komunikat operacyjny [z] 30 VII 1920 r., 30 VII 1920 r. [w:] ibidem, s. 530 . 
pochodzących najprawdopodobniej z rekwizycji, oraz wiozą ze sobą kobiety. Do zwiększenia popłochu przyczynia się w pierwszym rzędzie żandarmeria polowa z okręgu Kamieńca Podolskiego. Przejeżdżająca przez tut. Policja Państwowa z Kamieńca Podolskiego dały również dowody swej niekarności i braku dyscypliny wojskowej"78.

Krytyka spadła również na kozaków 3 DS: „Żołnierze wspomnianej grupy [co ciekawe, w tym czasie jeszcze nie sformowano Grupy gen. Udowyczenki, która również, wbrew twierdzeniom autora raportu, komisarza o nazwisku Łoziński, nie była «składową częścią 6 armii naszej» - M. K.] bosi i głodni, tudzież obdarci dopuszczają się również ekscesów, co więcej zmuszają ludność do przyjmowania hrywien, zdzierają napisy polskie, jak to miało miejsce we wsi Dawidkowce tut[ejszego] powiatu, oraz rozgłaszają pomiędzy ukraińską ludnością, że tu będzie Ukraina"79. W innym wypadku polscy policjanci z Trembowli skarżyli się na liczący 15 kozaków oddział należący jakoby do VII Brygady, który strzegł mostu na Serecie do dnia 23 lipca. Ukraińcy mieli się rzekomo zachowywać agresywnie wobec polskiej ludności, planowali zrywać polskie napisy, a nawet deklarowali sympatie probolszewickie oraz oświadczali, że „u nas każdy jest bolszewik, lecz nie komunista i na froncie do bolszewików strzelać nie będziemy, bo to jest nasz brat Rusin, raczej wolimy skierować broń przeciwko Polakom, niż ku bolszewikom" $"$.

Powyższe oskarżenia pod adresem tak 3 Żelaznej DS, jak i Armii URL były jednak w dużej mierze wytworem wyobraźni policjantów. Rzecz w tym, że w czasie sporządzenia raportu formacja gen. Udowyczenki, szczególnie jej VII Brygada, brała aktywny udział w walkach nad Zbruczem. Dowodem fałszu były ponadto doniesienia o rzekomych preferencjach politycznych i narodowościowych petlurowców, którzy byli przecież zdeklarowanymi wrogami bolszewizmu, czemu dawali wyraz wielokrotnie na polu walki. Tyczyło się to zwłaszcza kawalerii, która niejednokrotnie okrutnie postępowała z żołnierzami Armii Czerwonej - tak w walce, jak i po jej zakończeniu. Wielu ukraińskich kawalerzystów goliło ponadto głowy, zostawiając na niej jedynie tzw. śledzia, popularną fryzurę kozacką - jej posiadacze nie mogli jednak liczyć na pardon ze strony bolszewików. Był to świadomy wybór kozaków ${ }^{81}$.

78 Dok. Nr 246. Raport sytuacyjny do okręgowej komendy Policji Państwowej „Wschód” we Lwowie, 29 VII 1920 r. [w:] ibidem, s. 463-464.

79 Ibidem.

80 Dok. Nr 284. [Informacja] Organizacja Ukr[aińska] do Komendy Policji Państwowej na Małopolske we Lwowie, Trembowla, 23 VII 1920 r. [w:] ibidem, s. 525-526.

${ }_{81}$ G. Skrukwa, Formacje wojskowe ukraińskiej „rewolucji narodowej” 1914-1921, Toruń 2008, s. 244. 
Na dodatek żaden z ukraińskich żołnierzy pochodzących z Naddnieprza nie określiłby samego siebie mianem „Rusina”! Do tego, zdecydowanie nieaktualnego już terminu, przywiązała się za to polska prasa oraz wielu Polaków ${ }^{82}$.

Wspomniane fragmenty raportów zdradzały przede wszystkim obawy polskiej ludności przed wojskiem ukraińskim ${ }^{83}$, na co wpływ miała oczywiście wojna polsko-ukraińska $1918-1919^{84}$, ale w nikłym stopniu odpowiadały rzeczywistości. W tym czasie nie doszło ani do antypolskiego powstania w strefie kontrolowanej przez Armię URL, ani do masowego przejścia na stronę Armii Czerwonej. Pod koniec sierpnia 1920 r. miała miejsce jedynie dezercja części 5 Dywizji Chersońskiej, której wielu oficerów i kozaków było z pochodzenia Haliczanami, z oczywistych powodów niechętnymi Polsce. Jej też żołnierze odpowiadali głównie za sporadyczne wypadki zrywania tablic z polskimi napisami. Nie przeszli przy tym na stronę wroga, ale zbiegli do Czechosłowacji ${ }^{85}$. Zgodne z prawdą są jednak doniesienia o rekwizycjach oraz zmuszaniu ludności cywilnej do przyjmowania ukraińskich pieniędzy, co potwierdzają inne dokumenty ${ }^{86}$.

W pierwszych dniach sierpnia $1920 \mathrm{r}$. bolszewicy przygotowywali się do kolejnego uderzenia na siły ukraińskie. 2 sierpnia gen. OmelianowyczPawłenko postawił w stan gotowości 3 Żelazną DS oraz rozkazał wysłanie pułku kawalerii Frołowa w rejon wsi Laskowce, gdzie miał on nawiązać kontakt z oddziałem płk. Wacława Pażusia z 12 DP oraz lewym skrzydłem 1 Zaporoskiej DS. „Żelazna” miała być przygotowana do zajęcia stanowisk na linii Połowce-Słobodka Dżuryńska i wykonania kontrnatarcia w kierunku Czortkowa w razie odwrotu „Zaporożców” i 4 Kijowskiej DS. 3 Żelazną DS miała w takim wypadku wesprzeć SDK ${ }^{87}$.

Obawy dowódcy Armii Czynnej URL okazały się słuszne. Tego samego dnia oddziały Armii Czerwonej przeprowadziły wiele ataków demonstracyjnych,

${ }^{82}$ Zob. szerzej: H. Sojka-Mastalerz, Rusini czy Ukraińcy? Językowy obraz nacji ukraińskiej w prasie polskiej (1918-1939), Wrocław 2004.

${ }_{83}$ Zob. M. Klimecki, Galicja..., s. 120-121.

84 Więcej na temat tego konfliktu, zob. m.in. M. Łytwyn, Ukrajinśko-polśka wijna 1918-1919 rr., Lwiw 1998; M. Klimecki, Lwów 1918-1919, Warszawa 1998; idem, Polsko-ukraińska wojna o Lwów i Galicję Wschodnią 1918-1919, Warszawa 2000.

${ }^{85}$ Na temat tego epizodu zob. szerzej: A. Rukkas, Razem..., s. 250-251.

86 Zob. np. Dok. nr 545. Fonogram komendy powiatowej Policji Państwowej, Buczacz, 31 VII 1920 r. [w:] Bitwa lwowska..., t. I, s. 909.

${ }^{87}$ Dok. Nr 249. Wsim Komdywam, Zrazok Dowudstwu 12 Polśkoji Diwizii i 6 Polśkoji Armii cz. 890, Buczacz, 2 VIII 1920 r. [w:] Ukrajinśko-moskowśka..., s. 124-125; Dok. Nr 454. [Rozkaz] do wszystkich dowódców dywizji. Odpis do dowództwa 12 Polskiej Dywizji [Piechoty] i Polskiej 6 Armii, 2 VIII 1920 r. [w:] Bitwa lwowska..., t. I, s. 757-758. 
wspieranych ogniem broni maszynowej i artylerii, na odcinku od Dniestru do Ulaszowiec. Główne uderzenie miało miejsce pod Rosochaczem, gdzie bolszewicy przeprawili się przez Seret i następnie zaatakowali Jagielnicę na styku 1 oraz 4 Dywizji. Później cztery pułki bolszewickie (dwa kawalerii i dwa strzeleckie) zaczęły obchodzić prawe skrzydło „Zaporożców” w rejonie Białobożnicy. W celu zlikwidowania zagrożenia wysłano do kontrataku na Jagielnicę Starą VII Brygadę 3 Dywizji. Siły rzucone do walki okazały się jednak niewystarczające - przed wysłaniem „Żelaznych” błędnie oszacowano siły przeciwnika na jedynie 150 szabel. Atak nie powiódł się i Ukraińcy musieli przejść do defensywy. Bolszewicy zdobyli ponadto wieś Połowce. Zagrożona oskrzydleniem VII Brygada wycofała się w rejon Trybuchowce-Słobódka Dżuryńska. Nad ranem, 3 sierpnia, kawaleria bolszewicka zagroziła również prawemu skrzydłu VIII Brygady, która osłaniała drogę Dżuryn-Buczacz. Wycofała się ona na zachodni brzeg Strypy. Dowództwo Armii Czynnej wyznaczyło jako punkt zborny dla rozproszonej 3 Dywizji miejscowość Jezierzany. Sukcesy na froncie odniosły za to inne dywizje ukraińskie i przede wszystkim polska $12 \mathrm{DP}$, dzięki czemu nie doszło do natychmiastowego odwrotu za kolejną galicyjską rzekę ${ }^{88}$.

Po intensywnych walkach $w$ rejonie Jagielnicy stan żywieniowy 3 Żelaznej DS wyniósł 998 oficerów i 3457 kozaków. Tym samym była ona najsilniejszą formacją Armii Czynnej URL - była dwa razy silniejsza liczebnie od 2 Wołyńskiej DS (2024 oficerów i kozaków) i niemal trzykrotnie od 4 Kijowskiej DS (1480 oficerów i kozaków). Jej brygada zapasowa liczyła z kolei 111 oficerów i 206 kozaków w stanie żywieniowym ${ }^{89}$.

W dniach 4-6 sierpnia 1920 r. Ukraińcy podjęli próbę wyparcia Armii Czerwonej znad Strypy i Seretu. 4 sierpnia 3 Żelazna DS ruszyła do natarcia na obsadzone przez bolszewików wzgórza na zachód od wsi Bazar-Pauszówka-Dżuryn. Podwładni gen. Udowyczenki odbili ostatnią z miejscowości,

${ }^{88}$ Dok. Nr 260. Operatywnyj zwit do 8 hodyn 3 serpnia 1920 r.cz. 0909, Jezierzany, 3 VIII 1920 r. [w:] Ukrajinśko-moskowśka..., s. 128; Dok. nr. 333. Iż swodki operatywnago atdieła połewogo sztaba Rewwojensawieta Respubliki o pałażenii na Juga-Zapadnom Frontie, b.m., 4 VIII 1920 r. [w:] Grażdanskaja..., s. 338; Dok. Nr 456. [Rozkaz] do dowódcy Samodzielnej Konnej Dywizji, do wiadomości dowódcy 3 Strz[eleckiej Żelaznej] Dywizji i do wiadomości dowódcy 1 Zaporoskiej Dywizji, Buczacz, 2 VIII 1920 r. [w:] Bitwa lwowska..., t. I, s. 759; Dok. Nr 457. Komunikat operacyjny [wieczorny] do godz. 20 [dn.] 2 VIII 1920 r., Buczacz, 2 VIII 1920 r. [w:] ibidem, s. 760; Dok. Nr 458. Komunikat operacyjny 2 VIII 1920 r., b.m., 2 VIII 1920 r. [w:] ibidem, s. 761; Dok. Nr 492. Komunikat operacyjny do godz. 8 [dn.] 3 VIII 1920 r., 3 VIII 1920 r. [w:] ibidem, s. 818-819; Dok. Nr 494. Komunikat operacyjny sztabu Armii URL [z] 3 VIII 1920 r., b.m., 3 VIII 1920 r. [w:] ibidem, s. 820-821; O. Udowyczenko, Tretja Zalizna..., s. 72-73; J. Legieć, Armia..., s. 124-125.

${ }^{89}$ Dok. Nr 547. [Meldunek] do dowództwa 6 Armii, b.m., 4 VIII 1920 r. [w:] Bitwa lwowska..., t. I, s. 912. 
jednak z powodu zmęczenia żołnierzy dowódca Armii Czynnej nakazał odłożyć dalsze natarcie na następny dzień ${ }^{90}$. Na rozkaz gen. Omelanowycza-Pawłenki dowódcy 3 Dywizji podporządkowano również 1 Dywizję Zaporoską (297 oficerów i 1993 kozaków stanu żywnościowego), tworząc $\mathrm{w}$ ten sposób grupę bojową. Jej zadaniem było uderzenie $\mathrm{z}$ rana 5 sierpnia na pozycje bolszewickie i osiągnięcie linii Bazar-Antonówka-Dżuryn-Kosów-Laskowce. Na barkach 3 DS spoczywało wyprowadzenie decydującego uderzenia w kierunku na Dżuryn, po czym miała przejść do rezerwy Grupy gen. Udowyczenki. Ukraińcy mieli przy tym utrzymywać łączność z prawym skrzydłem Grupy płk. Pażusia. Z kolei prawe skrzydło Grupy gen. Udowyczenki miała osłaniać SDK ${ }^{91}$.

Walki z dnia 5 sierpnia 1920 r. nie przyniosły oczekiwanego rezultatu. Bolszewicy podejmowali działania zaczepne, przez co w wielu miejscach Ukraińcy musieli skupić się na defensywie. „Czerwoni” nie zdołali jednak wbić się między lewe skrzydło Grupy gen. Udowyczenki a Grupę płk. Pażusia. Bolszewikom nie udało się również utrzymać przyczółków na zachodnim brzegu Strypy. Do godz. 21:00 Ukraińcy odrzucili przeciwnika za rzekę. 6 sierpnia Grupa gen. Udowyczenki ponownie ruszyła do ataku i zajęła rejon Pomorce-Rzepińce. 3 Żelazna DS musiała jednak wstrzymać natarcie, gdyż 4 Kijowska DS, po początkowych sukcesach, pod naporem przeciwnika musiała się wycofać na prawy brzeg Strypy. W sytuacji, gdy skrzydła 3 Żelaznej DS były narażone na uderzenia przeciwnika, gen. Omelianowycz-Pawłenko wydał jej rozkaz odwrotu. Tego dnia Dywizja straciła 3 zabitych oficerów oraz 4 oficerów i 10 kozaków, którzy zostali ranni ${ }^{92}$.

90 Dok. Nr 264. Dodatok do operatyw. zwitu z 4/8 cz. 915, b.m., 4 VIII 1920 r. [w:] Ukrajinśko-moskowśka..., s. 130; Dok. Nr 265, Operatywnyj zwit za 4 serpnia do 17 hodyn, b.m., 4 VIII 1920 r. [w:] ibidem, s. 130; Dok. Nr 269. Tajemno. Nakaz Wijśkam Dijewoji Armii UNR cz. 0145, Korościatyń, 5 VIII 1920 r. [w:] ibidem, s. 131-132; Dok. Nr 551. Komunikat Operacyjny do godz. 17. [dn.] 4 VIII [1920 r.], b.m., 4 VIII 1920 r. [w:] Bitwa lwowska..., t. I, s. 916; O. Udowyczenko, Tretja Zalizna..., s. 73.

${ }^{91}$ Dok. Nr 549. Rozkaz do gen. Udowyczenko i d[owód]cy Samodzielnej Konnej Dywizji, kopia do dowództwa 6 Armii Wojsk Polskich, St. Korościatyn, 4 VIII 1920 r. [w:] Bitwa lwowska..., t. I, s. 914; Dok. Nr 593. Rozkaz do Armii Czynnej URL, Korościatyn, 5 VIII 1920 r. [w:] ibidem, s. 978.

${ }_{92}$ Dok. Nr 274. Henerałam Udowyczenko i Zahrodśkomu, Połkownykowi Omelianowyczu Pawłenko cz. 14, Korościatyn, 6 VIII 1920 r. [w:] Ukrajinśko-moskowśka..., s. 134; Dok. Nr 276. Operatywnyj zwit do 24 hodyny 6 serpnia 1920 r.cz. 16/k, Korościatyn, 6 VIII 1920 r. [w:] ibidem, s. 134-135; Dok. Nr 596. Komunikat operacyjny sztabu Armii URL [z] 5 VIII 1920 r., b.m., 5 VIII 1920 r. [w:] Bitwa lwowska..., t. I, s. 981; Dok. Nr 31. [Rozkaz] do gen. Udowiczenko, gen. Zagrodzkiego i płk. Omelianowycza-Pawlenki, b.m., 6 VIII 1920 r. [w:] ibidem, t. II, s. 54; Dok. Nr 33. Komunikat operacyjny 6 VIII 1920 r., b.m., 6 VIII 1920 r. [w:] ibidem, s. 55; Dok. Nr 73. Komunikat operacyjny do godz. 24 [dn.] 6 VIII 1920 r., Korościatyn, 7 VIII 1920 r. [w:] ibidem, s. 104-105; O. Udowyczenko, Tretja Zalizna..., s. 74. 
Od 7 sierpnia 1920 r. Armia Czynna URL była zmuszona prowadzić działania defensywne w oparciu o Strypę. Było to spowodowane zmęczeniem formacji ukraińskich, niedostatkiem amunicji oraz zagrożeniem lewego skrzydła Armii Czynnej URL. Sąsiadująca od północy z 3 Żelazną DS polska 12 DP była mocno wyczerpana oraz poniosła w wyniku ostatnich walk ciężkie straty ${ }^{93}$. Za Strypą dywizję gen. Udowyczenki przeniesiono do rezerwy w rejon Barysz-Jezierzany-Wierzbiatyn ${ }^{94}$.

9 sierpnia 1920 r. 3 Dywizja otrzymała rozkaz wysłania 100 kawalerzystów z działami polowymi na wzgórze 350, leżące na północ od wsi Jezierzany. Celem „Żelaznych” była obserwacja pozycji przeciwnika i wsparcie natarcia 1 Dywizji Zaporoskiej, SDK i VII Brygady z 3 DS na rejon wsi Przewłoka i Osowce. Walki prowadzone do późnego wieczora nie przyniosły ostatecznie rozstrzygnięcia. Bolszewicy utrzymali swoje pozycje w lesie na zachód od Osowiec. Podejmowali również próby ataku w kierunku miasta Barysz. VII Brygadzie udało się jednak odbić Przewłokę i wyprzeć przeciwnika na północny wschód od wioski. Sytuację sił ukraińskich skomplikowało zajęcie ok. godz. 20:00 Buczacza i pobliskiej stacji kolejowej przez „czerwonych”. Ponadto oddział bolszewicki w sile ok. 200 bagnetów i 30-50 szabel sforsował Strypę pod wsią Rusiłów i stworzył tam przyczółek. Zmusiło to gen. Udowyczenkę do wydania rozkazu kontrataku dla 1 Dywizji oraz własnej 3 DS w kierunku Buczacza. Brygady VIII i IX uderzyły na okoliczne wsie, podczas gdy wyczerpana VII Brygada i 3 pk pozostały w rezerwie. W ataku wspierał je pociąg pancerny „Karmeluk”. Buczacz został odbity przez 1 Dywizję. W wyniku walk bolszewicy stracili 50 zabitych, wielu rannych, 15 wziętych do niewoli, 12 taczanek z karabinami maszynowymi, 5 lekkich karabinów maszynowych i kancelarię 364 p. strz. Po zwycięstwie gen. Udowyczenko nakazał wystawić forpoczty nad rzeką, podczas gdy główne siły dywizji miały się cofnąć o kilka kilometrów ${ }^{95}$.

${ }_{93}$ J. Legieć, Armia..., s. 125.

${ }_{94}$ Dok. Nr 76. Rozkaz do wojsk Armii Czynnej, Korościatyn, 7 VIII 1920 r. [w:] Bitwa lwowska..., t. II, s. 107.

${ }^{2}$ Dok. Nr 287. Operatywnyj zwit do 7 hodyn 10 serpnia 1920 r. cz. 0957, Korościatyn, 10 VIII 1920 r. [w:] Ukrajinśko-moskowśka..., s. 141; Dok. Nr 289. Operatywnyj zwit do 17 hod. 10 serpnia 1920 r. cz. 0967, Korościatyn, 10 VIII 1920 r. [w:] ibidem, s. 141; Dok. Nr 290. Operatywnyj zwit do 23 hod. 10 serpnia 1920 r. cz. 35/k, Korościatyn, 10 VIII 1920 r. [w:] ibidem, s. 141-142; Dok. Nr 298. Operatywnyj zwit do 7 hodyn 12 serpnia 1920 r. cz. 0980, Korościatyn, 12 VIII 1920 r. [w:] ibidem, s. 145; Dok. Nr 175. Komunikat operacyjny do godz. 8.00 [dn.] 9 VIII 1920 r., Korościatyn, 9 VIII 1920 r. [w:] Bitwa lwowska..., t. II, s. 239; Dok. Nr 176. [Rozkaz] do dowódców dywizji 1 Zaporoskiej, Samodzielnej Konnej i 3 Żelaznej, kopia do dowódcy [2] Wołyńskiej Dywizji, Korościatyn, 9 VIII 1920 r. [w:] ibidem, s. 240; Dok. Nr 177. Komunikat operacyjny do godz. 18.00 [dn.] 9 VIII 1920 r., Korościatyn, 9 VIII 1920 r. [w:] ibidem, s. 240-241; Dok. Nr 178. Komunikat operacyjny 9 VIII 1920 r., Korościatyn, 9 VIII 1920 r. [w:] ibidem, s. 241; Dok. Nr 276. Komunikat operacyjny ogólny 
11 sierpnia 1920 r. bolszewicy ponownie zajęli Buczacz. Wywiad ukraiński ustalił skład zgrupowania przeciwnika: 364 i 366 p. strz. (ostatni w sile ok. 120 bagnetów z 3 karabinami maszynowymi). Jako rezerwę wróg posiadał 115 i 116 pk $^{96}$. Następnego dnia Ukraińcy przeprowadzili kontratak na pozycje przeciwnika. Natarcie powiodło się i bolszewicy rzucili się do ucieczki. W wyniku pościgu udało się odbić Buczacz i wyprzeć przeciwnika za Strypę, „Zadając nieprzyjacielowi duże straty w zabitych i rannych”97. W tym samym czasie stan żywieniowy 3 Żelaznej DS wynosił 872 oficerów, 3580 kozaków i 1793 konie, a bojowy 195 oficerów, 1367 bagnetów i 530 szabel $^{98}$.

16 sierpnia miał miejsce trzeci atak bolszewicki, który zakończył się zdobyciem Buczacza. Wieczorem tego samego dnia oddziały ukraińskie (w tym VII Brygada z 3 Dywizji) przeszły do kontrataku, dzięki któremu odbito część wiosek w okolicy miasta. 17 sierpnia VII Brygada zaatakowała Buczacz, jednak poniosła porażkę. Ukraińcom udało się zająć okoliczne wzgórza, z których zamierzali ostrzeliwać przeciwnika ${ }^{99}$.

za 8-10 VIII 1920 r., Korościatyn, 11 VIII 1920 r. [w:] ibidem, s. 345-346; O. Udowyczenko, Tretja Zalizna..., s. 74-76. Kozacy 3 Żelaznej DS zostali docenieni za swą postawę na polu bitwy w dniach 9-10 sierpnia pochwałą dowództwa Armii Czynnej URL. W tym samym rozkazie wyróżniono sotnyka Frołowa za wkład w rozbudowanie 3 pk, którego stan bojowy, pomimo aktywnego udziału w walkach, wzrósł do 300 szabel, 12 karabinów maszynowych i jednego działa polowego. Generał Omelanowycz-Pawłenko zabronił mu jednak „przeciągać do pułku oficerów i kozaków z innych oddziałów armii bez zgody na to dowódców zgodnie z istniejącymi uprawnieniami"; zob. Dok. Nr 321. Rozkaz do wojsk Armii Czynnej URL, b.m., 12 VIII 1920 r. [w:] Bitwa lwowska..., t. II, s. 391. Taktyka zakładająca wystawianie niewielkich straży przednich nad rzeką miała kilka zalet. Gdy przeciwnik prowadził ostrzał artyleryjski na przednie pozycje ukraińskie, to większość pocisków trafiała w „próżnię”. Po przekroczeniu rzeki na bolszewików uderzały silne oddziały ukraińskie, które, zadając przeciwnikowi duże straty, „wyrzucały” go za rzekę.

96 Dok. Nr 291. Rozwidocznyj zwit Sztabu Armii UNR. do 8 hodyn 11. VIII. 920. cz. 132/rz, b.m., 11 VIII 1920 r. [w:] Ukrajinśko-moskowśka..., s. 142; Dok. Nr. 292. Operatywnyj zwit do 8 hodyn 11 serpnia 1920 r. cz. 0969, Korościatyn, 11 VIII 1920 r. [w:] ibidem, s. 142; Dok. Nr 299. Rozwidocznyj zwit Sztadarmu UNR do 8 hod. 12. VIII. 920. cz. 134, b.m., 12 VIII 1920 r. [w:] ibidem, s. 145; O. Udowyczenko, Tretja Zalizna..., s. 76.

${ }_{97}$ Dok. Nr 301. Operatywnyj zwit do 11 hodyn 12 serpnia 1920 r.cz. 0993, Korościatyn, 12 VIII 1920 r. [w:] Ukrajinśko-moskowśka..., s. 146-147; Dok. Nr 302. Operatywnyj zwit do 17 hodyn 12 serpnia 1920 r. cz. 0997, Korościatyn, 12 VIII 1920 r. [w:] ibidem, s. 147; Dok. Nr 323. Meldunek operacyjny do godz. 11.00 [dn.] 12 VIII 1920 r., Korościatyn, 12 VIII 1920 r. [w:] Bitwa lwowska..., t. II, s. 392; Dok. Nr 324. Meldunek operacyjny do godz. 17.00 [dn.] 12 VIII 1920 r., Korościatyn, 12 VIII 1920 r. [w:] ibidem, s. 392; O. Udowyczenko, Tretja Zalizna..., s. 76 .

98 CDAWOWUUK, f. 1075, op. 2, sp. 286, Zestawienie stanów liczebnych Armii Czynnej URL na dni 15 i 31 VIII 1920 r. w j. ukr., b.m. 31 VIII 1920 r., k. 19; Z. Karpus, Wschodni sojusznicy..., s. 32; A. Rukkas, Razem..., s. 245.

99 Dok. Nr 317. Operatywnyj zwit do 8 hodyn 17 serpnia 1920 r. cz. 01029, Korościatyn, 17 VIII 1920 r. [w:] Ukrajinśko-moskowśka..., s. 150; Dok. Nr 319. Operatywnyj zwit do 16 hodyn 17 
Działania zmierzające do odzyskania Buczacza i wyparcia oddziałów bolszewickich za Strypę zostały wstrzymane 18 sierpnia. Powodem decyzji dowódcy Armii Czynnej URL była wiadomość o przełamaniu przez przeciwnika frontu polskiej 6 Armii. W tym czasie 1 Armia Konna kontynuowała natarcie na Lwów. Ciężkie straty na froncie zmusiły polskie dowództwo do skierowania niemal całej 6 Armii przeciwko konnicy Budionnego. Front na południe od Lwowa miały wspólnie utrzymać jedynie Armia Czynna URL i polska 12 DP. Nie widząc sensu obrony linii Strypy, dnia 19 sierpnia gen. Omelianowycz-Pawłenko i płk Januszajtis wycofali swe oddziały za Dniestr. Po przekroczeniu rzeki 3 Dywizja miała ześrodkować się w rejonie Korościatyń-Monasterzyska-Dubienka-Huta Stara i obsadzić linię frontu: Zubrzec-Barysz-Jezierzany-Kowalówka-Czeremchów (ok. 20 km) oraz prowadzić rozpoznanie przed swymi liniami ${ }^{100}$.

Kolejny odwrót z pewnością spowodował spadek morale wśród kozaków. Na dodatek Armia Czerwona nadal naciskała na pozycje ukraińskie. Przed południem silny oddział bolszewicki zaatakował stanowiska 3 Żelaznej DS pod Baryszem. Jednak jeszcze wieczorem 18 sierpnia do dowództwa Armii Czynnej URL nadeszła wiadomość o klęsce Armii Czerwonej pod Warszawą. Informacja ta dała Ukraińcom nadzieję na zwycięstwo i powrót nad Dniepr. Pod jej wpływem gen. Omelianowycz-Pawłenko zakazał niszczenia mostów na Dniestrze i nakazał utrzymać przyczółki na jego wschodnim brzegu. Oczekiwano dalszych informacji o rozwoju sytuacji na innych odcinkach frontu ${ }^{101}$.

serpnia 1920 r. cz. 01030, Korościatyn, 17 VIII 1920 r. [w:] ibidem, s. 150-151; Dok. Nr 420. Meldunek rozpoznawczy sztabu Armii URL do godz. 9.00 [dn.] 17 VIII 1920 r., b.m., 17 VIII 1920 r. [w:] Bitwa lwowska..., t. II, s. 527; Dok. Nr 422. Komunikat operacyjny do godz. 8.00 [dn.] 17 VIII 1920 r., Korościatyn, 17 VIII 1920 r. [w:] ibidem, s. 529-530; Dok. Nr 423. Komunikat operacyjny do godz. 16.00 [dn.] 17 VIII 1920 r., b.m., 17 VIII 1920 r. [w:] ibidem, s. 530; Dok. Nr 424. Komunikat operacyjny sztabu Armii URL [z dn.] 17 VIII 1920 r. [w:] ibidem, s. 530; O. Udowyczenko, Tretja Zalizna..., s. 76-77; J. Legieć, Armia..., s. 126.

100 Dok. Nr 324. Nakaz Wijśkam Dijewoji Armii U. N. R. cz.0151, Korościatyn, 18 VIII 1920 r. [w:] Ukrajinśko-moskowśka..., s. 155-157; Dok. Nr 449. Rozkaz do wojsk Armii Czynnej URL, Korościatyn, 18 VIII 1920 r. [w:] Bitwa lwowska..., t. II, s. 557-558; Dok. Nr 507. Komunikat operacyjny do godz. 16.00 [dn.] 19 VIII 1920 r., Chryplin, 19 VIII 1920 r. [w:] ibidem, s. 614; O. Udowyczenko, Tretja Zalizna..., s. 78; J. Legieć, Armia..., s. 126-127 i 131.

101 Dok. Nr 327. Komdiwam 1 Zapororzśkoji, 2 Wołynśkoji, 3 Striłećkoji, 4 Kyjiwskoji, 5 Chersonśkoji, 6 Striłećkoji, Okremoji kinnoji, Naczalnyku Zapasowych bryhad i Naczalnyku tyła cz. 0153, b.m., 19 VIII 1920 r. [w:] Ukrajinśko-moskowśka..., s. 158; Dok. Nr 450. Komunikat operacyjny do godz. 16.00 [dn.] 18 VIII 1920 r., Korościatyn, 18 VIII 1920 r. [w:] Bitwa lwowska..., t. II, s. 561; Dok. Nr 451. Rozkaz [do] dowódcy dywizji: 1 Zaporoskiej, 2 Wotyńskiej, 3 [Żelaznej] Strzeleckiej, 4 Kijowskiej, 5 Chersońskiej, 6 [Siczowej] Strzeleckiej, Samodzielnej Jazdy, Naczelników brygad zapasowych, szefów tyłów, Korościatyn, 18 VIII 1920 r. [w:] ibidem, s. 561-562; J. Legieć, Armia..., s. 131-132. 
W momencie przekroczenia Dniestru w nocy z 19 na 20 sierpnia $1920 \mathrm{r}$. 3 Żelazna DS liczyła w stanie bojowym: 195 oficerów, 1367 bagnetów, 530 szabel, 78 karabinów maszynowych i 12 dział ${ }^{102}$. Formacja została rozlokowana w rejonie Ciężów-Pawłecze-Majdan-Bednarów. W Majdanie zakwaterowano sztab dywizji. Głównym zadaniem „Żelaznych” miała być obrona przepraw na Dniestrze, głównie w okolicy Martynowa oraz na Łomnicy koło Wistowy. Tymczasowo podporządkowano rozkazom jej dowódcy pociąg pancerny "Czarnomorec" ${ }^{\prime 103} .20$ sierpnia gen. Udowyczenko otrzymał rozkaz wysłania 3 pk płk. Frołowa w kierunku wsi Wojniłów i Podgrodzie z zadaniem zlokalizowania, wraz z SDK, oddziału jazdy bolszewickiej z 8 DK „Czerwonego Kozactwa", która przebiła się na tyły wojsk polskich i ukraińskich. Piechota 3 Dywizji miała z kolei strzec dotychczasowych pozycji, obsadzonych zgodnie z poprzednim rozkazem dowódcy Armii Czynnej ${ }^{104}$. Kawalerzystom Frołowa nie przyszło jednak stoczyć zaciętych walk z bolszewikami. Okazało się, że siły przeciwnika były nieznaczne - albo doniesienia wywiadu okazały się przesadzone, albo „czerwoni” postanowili w porę wycofać się ${ }^{105}$.

22 sierpnia bolszewicy ponieśli porażkę $\mathrm{w}$ trakcie forsowania Dniestru na odcinku obsadzonym przez siły ukraińskie. Tego samego dnia do sztabu 3 Żelaznej DS dotarł rozkaz odwrotu o kilkanaście kilometrów na południe, w kierunku Stanisławowa. Powyższa decyzja była podyktowana działalnością bolszewickiej 8 DK i obawą o jej ewentualny atak, przy współpracy z 41 DS, na lewe skrzydło Armii Czynnej URL. Bolszewicy nie zaatakowali jednak ukraińskich pozycji ${ }^{106}$.

25 sierpnia 1920 r. Ukraińcom udało się ponownie nawiązać kontakt z oddziałami polskimi. Armia Czynna URL otrzymała od dowództwa Frontu Południowego rozkaz prowadzenia działań zaczepnych przeciwko

102 Dok. Nr 323. Widomost' pro bojowyj stan Armii UNR. na 13/20 serpnia 1920, b.m., 20 VIII 1920 r. [w:] Ukrajinśko-moskowśka..., s. 154; Dok. Nr 575. Informacja o stanie bojowym Armii URL na [dzień] 13/20 VIII 1920 r., b.m., 20 VIII 1920 r. [w:] Bitwa lwowska..., t. II, s. 676; B. Skrobacz, Kawałerija..., s. 179.

103 Dok. Nr 506. Rozkaz [do] wojsk Armii Czynnej URL, Chryplin, 19 VIII 1920 r. [w:] Bitwa lwowska..., t. II, s. 613-614.

104 Dok. Nr 332. Komdiwu Okremoji i 3 Zaliznoji cz. 62, Chryplin, 20 VIII 1920 r. [w:] Ukrajinśko-moskowśka..., s. 160-161; Dok. Nr 576. [Rozkaz] do dowódców Dywizji: Samodzielnej Konnej i 3 Żelaznej, Chryplin, 20 VIII 1920 r. [w:] Bitwa lwowska..., t. II, s. 678-679; O. Udowyczenko, Tretja Zalizna..., s. 79-80.

105 Dok. Nr 581. Komunikat operacyjny sztabu Armii URL, Chryplin, 20 VIII 1920 r. [w:] Bitwa lwowska..., t. II, s. 680 .

106 Dok. Nr 346. Nakaz Wijśkam Dijewoji Armii U. N. R. cz. 0156, Chryplin, 22 VIII 1920 r. [w:] Ukrajinśko-moskowśka..., s. 167-168; O. Udowyczenko, Tretja Zalizna..., s. 81; J. Legieć, Armia..., s. 133. 
bolszewickiej $14 \mathrm{Armii}^{107}$. W celu przełamania frontu przeciwnika pod Monasterzyskami utworzono Grupę gen. Udowyczenki, w składzie której znalazły się: 3 Żelazna DS, 4 Kijowska DS i Zbiorcza Dywizja Zapasowa (złożona z ukraińskich brygad zapasowych). Grupa miała 26 sierpnia zająć pozycje wyjściowe w rejonie Niżniowa. Jej lewe skrzydło osłaniała SDK, prawe Grupa gen. Ołeksandra Zahrodskiego (2 Wołyńska DS i 5 Chersońska DS). $\mathrm{Na}$ kierunku natarcia formacji Armii Czynnej URL bolszewicy dysponowali 122 BS i dwoma pułkami ze 123 BS. Razem siły te liczyły w stanie bojowym ok. 2 tys. bagnetów i 700 szabel $^{108}$.

Rankiem 27 sierpnia 1920 r. po ostrzale artyleryjskim do ataku ruszyła VII Brygada. Udało jej się zająć przyczółek nad Dniestrem. Mimo że pozostałym brygadom nie udało się sforsować rzeki, to jednak wyparły $366 \mathrm{p}$. strz. na jej wschodni brzeg, zadając mu jednocześnie duże straty. Ukraińcy wzięli do niewoli ok. 40 żołnierzy przeciwnika. Wieczorem gen. Udowyczenko rozkazał wstrzymać natarcie do następnego dnia. Nakazano jednak 3 pk działania zmierzające do rozpoznania sił oraz pozycji przeciwnika ${ }^{109}$. 28 sierpnia kawaleria ukraińska przełamała szarżą front 368 p. strz. i wyszła na tyły wojsk bolszewickich. Ukraińcom udało się również wkroczyć do Monasterzysk, ale zostali wyparci z miasta przez oddział kursantów moskiewskiej szkoły „Czerwonych Dowódców”, którego stan bojowy wynosił ok. 400 bagnetów. Sukces odnieśli za to kawalerzyści z VIII Brygady, rozbijając przeciwnika pod folwarkiem Werki. Poległo ok. 30 bolszewików. Ukraińcy stracili 7 zabitych (w tym jednego oficera) i 26 rannych. Jednak zbyt powolne postępy piechoty 3 Żelaznej DS pozwoliły przeciwnikowi ustabilizować front ${ }^{110}$.

Następnego dnia Grupa gen. Udowyczenki, przy wsparciu Grupy ppłk. Jana Rolińskiego, przełamała front pod Monasterzyskami, jednak nie była w stanie odbić miasta z rąk wroga. Dodatkowo kawaleria bolszewicka wyszła

107 Dok. Nr 357. Nakaz Wijśkam Dijewoji Armii U. N. R. cz. 0158, Otynia, 24 VIII 1920 r. [w:] Ukrajinśko-moskowśka..., s. 172-174; J. Legieć, Armia..., s. 133-134.

108 Dok. Nr 359. Rozwidocznyj zwit Sztadarmu UNR. za 24. VIII do 21 hoduni cz. 175/r., b.m., 24 VIII 1920 r. [w:] Ukrajinśko-moskowśka..., s. 175-176; Dok. Nr 367. Zi Sztabu Dijewoji Armii cz. 778, Otynia, 26 VIII 1920 r. [w:] ibidem, s. 177-178; O. Udowyczenko, Tretja Zalizna..., s. 82-83; P. Szandruk, Siła..., s. 110; J. Legieć, Armia..., s. 134.

109 Dok. Nr 368. Operatywnyj zwit do 8 hod. 27 serpnia cz. 01052, Chryplin, 27 VIII 1920 r. [w:] Ukrajinśko-moskowśka..., s. 178; Dok. Nr 370. Operatywnyj zwit do 16 hod. 27 serpnia cz. 01054, Chryplin, 27 VIII 1920 r. [w:] ibidem, s. 178-179; Dok. Nr 375. Operatywnyj zwit do 8 hodyn 28 serpnia 1920 r. cz. 01056, Chryplin, 28 VIII 1920 r. [w:] ibidem, s. 180-181; O. Udowyczenko, Tretja Zalizna..., s. 84; J. Legieć, Armia..., s. 134.

110 Dok. Nr 392. Operatywnyj zwit do 8 hod. 30 serpnia cz. 01060, Chryplin, 30 VIII 1920 r. [w:] Ukrajinśko-moskowśka..., s. 188-189; Dok. Nr 393. Nakaz Wijśkam Dijewoji Armii U. N. R. cz. 0163, b.m., 30 VIII 1920 r. [w:] ibidem, s. 189; O. Udowyczenko, Tretja Zalizna..., s. 84-85; J. Legieć, Armia..., s. 134; B. Skrobacz, Kawałerija..., s. 182. 
na tyły IX Brygady. W dniach 30 i 31 sierpnia „czerwoni”, po wzmocnieniu swoich oddziałów, sami przeszli do działań zaczepnych. Grupa gen. Udowyczenki została wyparta w okolice Niżniowa. W czasie ostatnich trzech dni walk o Monasterzyska 3 Żelazna DS straciła 1 zabitego oficera i 6 kozaków oraz 3 rannych oficerów i 18 kozaków. W tym czasie po stronie bolszewików poległo 15, a zostało rannych 45 żołnierzy. W ukraińskim komunikacie z 31 sierpnia pojawiła się informacja, że „wśród zabitych [przeciwników] znaleźli się Chińczycy"111.

31 VIII 1920 r. stan żywnościowy 3 Żelaznej DS wynosił 5192 oficerów i kozaków. Tym samym pozostawała ona nadal najsilniejszą formacją Armii Czynnej URL, której stan wynosił w tym czasie 22239 oficerów i kozaków. Zwraca uwagę fakt, że pomimo aktywnego udziału w ciężkich walkach na froncie liczebność 3 Dywizji systematycznie rosła. Od 15 sierpnia stan żywnościowy wzrósł o 103 oficerów, 637 kozaków i 808 koni ${ }^{112}$. 5 września wynosił on 993 oficerów, 4323 kozaków i 2684 konie ${ }^{113}$.

Na początku września 1920 roku 3 Żelazna DS została ponownie wysłana na tyły Armii Czynnej URL w celu uzupełnienia strat i odpoczynku. $\mathrm{Na}$ froncie pozostać miała tylko kawaleria dywizyjna, która też poniosła w ostatnich walkach najmniejsze straty, osiągając jednocześnie znacznie większe sukcesy niż piechota. Podporządkowano ją tymczasowo dowódcy 2 DS. 9 września dowódca Armii Czynnej URL nakazał przetransportowanie dywizji w okolice miast Horodenka i Czerniatyń, bliżej frontu. Decyzja ta miała związek z polsko-ukraińskimi przygotowaniami do ofensywy na Ukrainę, która miała pierwotnie ruszyć 13 września. Ostateczny termin jej rozpoczęcia przesunięto o dwa dni w skutek niespodziewanego ataku bolszewików w okolicach Rohatynia ${ }^{114}$.

Zadania dla dywizji ukraińskich zostały szczegółowo opisane w rozkazie z dnia 12 września:

111 Dok. Nr 397. Operatywnyj zwit do 8 hod. 31 serpnia cz. 01062, Chryplin, 31 VIII 1920 r.; [w:] Ukrajinśko-moskowśka..., Dok. Nr 398. Rozwidocznyj zwit Sztadarmu UNR 31. VIII do 9 hodyn cz. 200/r., b.m., 31 VIII 1920 r. [w:] ibidem, s. 191; O. Udowyczenko, Tretja Zalizna..., s. 85-89; P. Szandruk, Siła..., s. 111; J. Legieć, Armia..., s. 134-135.

112 CDAWOWUUK, f. 1075, op. 2, sp. 286, Zestawienie stanów liczebnych Armii Czynnej URL na dni 15 i 31 VIII 1920 r. w j. ukr., b.m. 31 VIII 1920 r., k. 19; sp. 381, Stan ljudej armiji U.N.R., b.m. 29 VIII 1920 r., k. 70.

113 Dok. Nr 30. [Meldunek] stan liczebny Armii Ukraińskiej, b.m., 5 IX 1920 r. [w:] Bitwa wotyńsko-podolska..., s. 54.

114 Dok. Nr 152. [Rozkaz] do dowódcy 3 Żelaznej [DS] i 6 [Siczowej] DS., Chryplin, 9 IX 1920 r. [w:] ibidem, s. 187; Dok. Nr 204. Komunikat operacyjny sztabu Armii URL [z] 11 IX 1920, b.m., 11 IX 1920 r. [w:] ibidem, s. 253-254; O. Udowyczenko, Tretja Zalizna..., s. 90 i 92-95; J. Legieć, Armia..., s. 161. 
„Forsować rz.[ekę] Dniestr na odcinku od rumuńskiej granicy do wsi Łuka w miejscach wybranych przez gen. Udowiczenkę [powinno być Udowyczenkę - M. K.] z takim wyliczeniem czasu, aby ze świtem 14 września przyczółek przeprawy był zabezpieczony dla swobodnego przejścia piechoty i artylerii. Zadania pierwszej fazy dla grupy - opanować piechotą rejon: Capowce-Popowce-Burakówka i uderzyć konnicą w kierunku na Dżuryn, Buczacz w celu przecięcia szlaków odwrotowych wroga i zniszczenia go. Następne zadanie grupy - opanowanie Czortkowa i linii dolnego Seretu i dalszy ruch 3 Żelaznej DS w kierunku na Skałat. Sztab grupy wraz z przesuwaniem się naprzód, pozostawi w m. Horodenka na centralnej stacji posterunek telegraficzny łączności i niezwłocznie będzie budować za sobą linię telegraficzną"115.

Pierwszym ważnym zadaniem, jakie miała wykonać 3 Żelazna DS, było wybudowanie mostu na Dniestrze. Most miał zostać wybudowany pod miejscowością Horodnica. 3 Pułk Inżynieryjny wytypował tę miejscowość jako najlepsze miejsce dla jego budowy ze względu na odległość między oboma brzegami (301 metrów) oraz bród. Okoliczne jary pozwalały na ukrycie znacznej ilości wojska przed oddziałami zwiadowczymi przeciwnika. Wreszcie w pobliżu Horodnicy znajdowały się dobre pozycje dla artylerii. 13 września inżynierom udało się mimo ostrzału karabinowego zbadać głębokość i stan dna rzeki. Okazało się, że największa głębokość wynosi 1,6 m, zaś dno było równe i twarde. Sztab dywizji ustalił, że kawaleria i artyleria będą mogły sforsować Dniestr w bród ${ }^{116}$.

Wschodni brzeg rzeki obsadzał 363 p. strz. w sile ok. 800 bagnetów, ok. 180-200 szabel, 15 karabinów maszynowych i 4 dział. Większość tych sił była rozlokowana w mieście Zaleszczyki (dwa bataliony strzeleckie). Stan bojowy 3 Żelaznej DS wynosił w tym czasie 451 oficerów, 1231 bagnetów, 749 szabel, 73 karabiny maszynowe oraz 11 lub 12 dział. W Grupie, nad którą dowództwo objął gen. Udowyczenko, znalazły się również 4 Kijowska DS (212 oficerów, 1104 bagnety, 129 szabel, 25 karabinów maszynowych i 9 dział), 5 Chersońska DS (92 oficerów, 96 bagnetów, 34 szable i 4 działa)

${ }^{115}$ Dok. Nr 459. Nakaz Wijśkam Dijewoji Armii Ukrainskoji Respubłyky cz. 0171, Stanisławów, 12 IX 1920 r. [w:] Ukrajinśko-moskowśka..., s. 216; Dok. Nr 234. Rozkaz do wojsk Armii Czynnej Ukraińskiej Republiki, Stanisławów, 12 IX 1920 r. [w:] Bitwa wołyńsko-podolska..., s. 286-287.

116 Dok. Nr 274. Rozkaz do wojsk Armii Czynnej Ukraińskiej Republiki, Stanisławów, 13 IX 1920 r. [w:] ibidem, s. 325; O. Udowyczenko, Tretja Zalizna..., s. 93-94 i 99-100; idem, Forsuwannja Dnistra pid Horodnyceju, „Za Derżawnist” (Kalisz) 1934, nr 4, s. 191-192. 


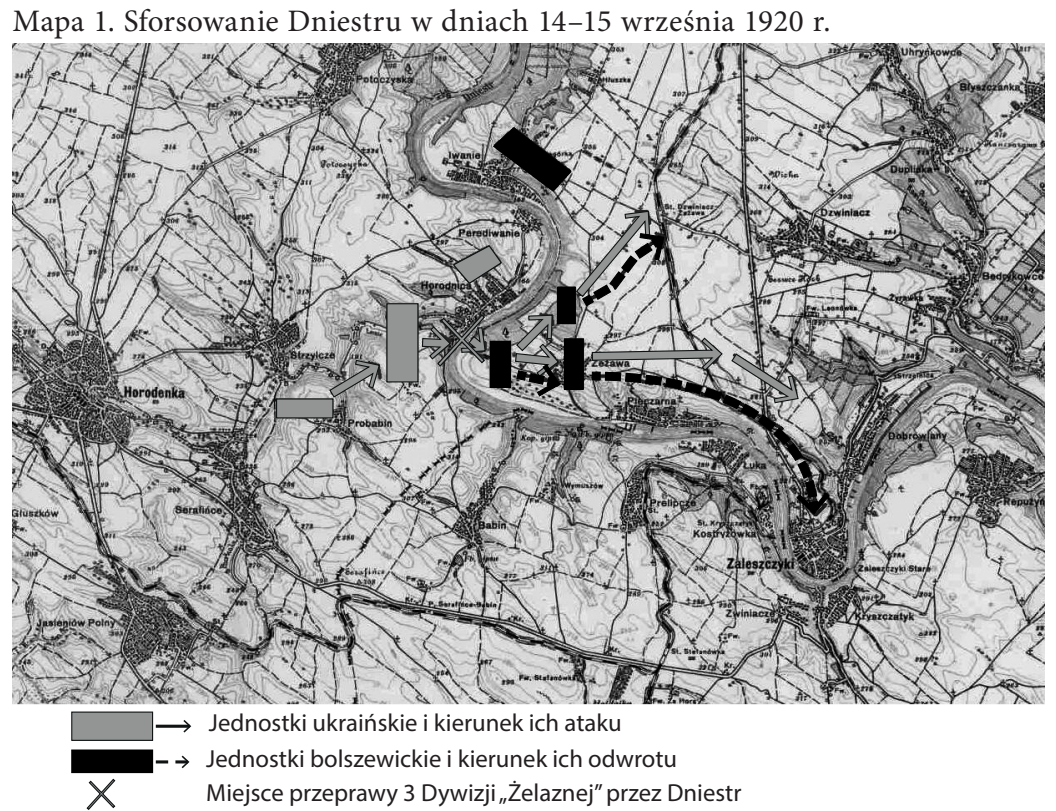

Autor: M. B. Kozubel. Źródło mapy: http://rzecz-pospolita.com

oraz Dywizja Karabinów Maszynowych ${ }^{117}$. W połowie września 1920 roku stan bojowy całej Armii Czynnej URL wynosił 2291 oficerów, 4345 bagnetów, 2043 szable, 44 działa i 324 karabinów maszynowych na stan żywieniowy liczący 3287 oficerów i 12117 kozaków ${ }^{118}$.

Przeprawę rozpoczęto w nocy z 14 na 15 września. Zanim 3 Pułk Inżynieryjny rozpoczął budowę mostu, artyleria ukraińska ostrzelała wschodni brzeg Dniestru. Następnie kawaleria sforsowała rzekę wpław, a piechota z VIII Brygady pokonała przeszkodę wodną na pontonach. „Posterunki wartownicze - wspominał tamte wydarzenia P. Szandruk - wroga zostały zajęte, żołnierze wzięci do niewoli, i czerwoni zaczęli wycofywać w panice". Przed południem oddziałom ukraińskim udało się odbić wieś Żeżawa położoną nad Dniestrem i wyprzeć bolszewików do Zaleszczyk, tworząc tym samym silny i rozległy przyczółek. 3 Pułk Kawalerii kontynuował również pościg za ustępującym przeciwnikiem, zadając mu ciężkie straty i zdobywając 6 karabinów maszynowych. „Żelaźni” odbili również miasto Tłuste. 15 września w wyniku walk 3 Żelazna DS poniosła niewielkie straty - ranny

117 Idem, Tretja Zalizna..., s. 101; idem, Forsuwannja Dnistra..., s. 193; Z. Karpus, Wschodni..., s. 35.

118 Dok. Nr 458. Widomost' pro skład Armii UNR 8/15 weresnia 1920 r., b.m., 15 IX 1920 r. [w:] Ukrajinśko-moskowśka..., s. 215. Zbigniew Karpus podaje inną liczbę Armii Czynnej w stanie żywieniowym (3456 oficerów i 12754 kozaków) oraz bojowym (1980 oficerów, 6142 bagnety i 2570 szabel). Do stanu bojowego zaliczono również rekrutów, których w tym czasie w szeregach Armii Czynnej było 2282; Z. Karpus, Wschodni..., s. 35. 
1 oficer i 22 kozaków, a w trakcie przeprawy zatonęly dwa wozy z karabinami maszynowymi i zaprzęgnięte w nie konie. Budowę mostu ukończono do wieczora 17 września. W pracy nad nim brało udział 30 oficerów, 440 kozaków i 100 robotników cywilnych wyposażonych w 2 ciężarówki, 50 wozów wojskowych i 120 wiejskich. 25 oficerów i 320 kozaków należało do 3 Pułku Inżynieryjnego ${ }^{119}$.

16 września 1920 r. 3 Żelazna DS odbiła Jagielnicę i stację Torskie, gdzie zdobyła 7 taczanek z karabinami maszynowymi i 18 jeńców. Aby nadążyć za szybko wycofującym się przeciwnikiem, sformowano grupę kawalerii pod dowództwem gen. Udowyczenki. W jej skład weszły 3 pk oraz 7 i 8 Sotnie Konne (każda $\mathrm{z}$ sotni w sile ok. 50 szabel). Stan bojowy grupy wyniósł ok. 400 szabel, 20 karabinów maszynowych i 2 lekkie działa. 17 września, pod Czortkowem, ukraińska kawaleria odniosła znaczny sukces. Wpierw 3 pk - przy wsparciu ogniowym 2 lekkich dział - rozbił oddział strzelecki, liczący ok. 500 bagnetów. Zaraz po tym starciu na 9 Sotnię Konną płk. Borysa Marenhowskiego ruszyła kawaleria bolszewicka w sile ok. 100 szabel. Jej szarża została zatrzymana ogniem dział i karabinów maszynowych. Straty bolszewickie spod Czortkowa wyniosły ok. 100 zabitych (dane raczej przesadzone) i 70 jeńców (zapewne wielu z nich było rannych), 2 karabiny maszynowe oraz tabor w liczbie ok. 100 wozów. Zginęli dowódcy bolszewickiego III/363 p. strz. i jednej z kompanii tegoż batalionu. Ukraińcy stracili 1 zabitego oficera i 9 rannych kozaków. Tego samego dnia 3 pk odbił Kopyczyńce, gdzie po rozebraniu torów udało mu się unieruchomić i zdobyć pociąg pancerny. W tym czasie 8 Sotnia Konna pod dowództwem sotnyka Antina Hamzy zajęła miasteczko Skała. 17 września Ukraińcy zdobyli Czortków. W wyniku walk kawaleria 3 Żelaznej DS rozbiła 363 p. strz., który stracił ok. 150 zabitych i 300 wziętych do niewoli żołnierzy ${ }^{120}$.

119 Dok. Nr 473. Operatywnyj zwit do 6 hodyn 15 weresnia 1920 r. cz. 01094, Stanisławów, 15 IX 1920 r. [w:] Ukrajinśko-moskowśka..., s. 222-223; Dok. Nr 474. Operatywnyj zwit do 12 hodyn 15 weresnia 1920 r. cz. 01095, Stanisławów, 15 IX 1920 r. [w:] ibidem, s. 223; Dok. Nr 475. Operatywnyj zwit do 18 hodyn 15 weresnia 1920 r.cz.01096, Stanisławów, 15 IX 1920 r. [w:] ibidem, s. 223; Dok. Nr 335. Komunikat operacyjny sztabu Armii URL [z] 15 IX 1920 r. [w:] Bitwa wolyńsko-podolska..., s. 406; O. Udowyczenko, Tretja Zalizna..., s. 102-107; idem, Forsuwannja Dnistra..., s. 195-200; P. Szandruk, Siła..., s. 111; J. Legieć, Armia..., s. 163.

120 Dok. Nr 482. Operatywnyj zwit do 12 hodyny 16 weresnia 1920 r. cz. 01099, Stanisławów, 16 IX 1920 r. [w:] Ukrajinśko-moskowśka..., s. 226; Dok. 483. Operatywnyj zwit do 18 hodyn 16 weresnia 1920 r. cz. 01100, Stanisławów, 16 IX 1920 r. [w:] ibidem, s. 226; Dok. Nr 488. Rozwidocznyj zwit Sztadarmu UNR. za 17 weresnia do 9 hod. cz. 236/rz., b.m., 17 IX 1920 r. [w:] ibidem, s. 227-228; Dok. Nr 492. Dodatok do Rozwidocznoho zwitu cz. 236 za 17 IX 1920 r., b.m., 17 IX 1920 r. [w:] ibidem, s. 230; Dok. Nr 365. Meldunek operacyjny do godz. 12.00, Stanisławów 16 IX 1920 r. [w:] Bitwa wołyńsko-podolska..., s. 445; Dok. Nr 397. Komunikat wywiadowczy Sztabu Armii URL za 17 IX 1920 r., b.m. 17 IX 1920 r. [w:] ibidem, s. 480; Dok. Nr 398. Dodatek do komunikatu wyw[iadu]. nr 236 z 17 IX 1920 r., b.m., 


\section{Powrót Armii URL na Podole. Szlak bojowy 3 Żelaznej Dywizji Strzeleckiej od przekroczenia Zbrucza do zawarcia rozejmu polsko-bolszewickiego (18 września - 18 października 1920 r.)}

W dniach 18-19 września 1920 r. Dywizja dotarła do Zbrucza. Jeszcze 19 września 8 Sotnia Konna wkroczyła do Orynina i pozostała w nim na noc. Następnego dnia, po zlikwidowaniu słabego oporu bolszewików, kawaleria 3 Żelaznej DS wkroczyła do Kamieńca Podolskiego. W wyniku walk „Żelazna” wzięła do niewoli 312 jeńców i zdobyła ok. 100 wozów ${ }^{121}$.

21 września 1920 r., gdy 3 DS miała uderzyć na Dunajowce, oddział bolszewicki (w sile ok. 400 bagnetów) z 361 p. strz. zaatakował pozycje VII Brygady pod wsią Latawa. Atak załamał się pod ogniem karabinowym i artyleryjskim. Następnie na wycofujący się oddział bolszewicki uderzyły 7 i 8 Sotnie Konne. Po tym starciu do ataku na wsie Siekiernice i Zielona ruszyła piechota 3 Żelaznej DS. W walce o obie miejscowości rozbito dwa bataliony z 361 p. strz. W wyniku starć stoczonych 21 września Ukraińcy wzięli do niewoli 32 jeńców oraz zdobyli karabin maszynowy. W walce poległo 70 bolszewików ${ }^{122}$.

Następny dzień na froncie Dywizji upłynął dosyć spokojnie. Gen. Udowyczenko zdecydował się skierować uderzenie swej dywizji na północ w celu wsparcia działań innych formacji Armii Czynnej URL. 23 września pod Dunajowcami 3 Żelazna DS rozbiła liczący 200 bagnetów i kilkadziesiąt szabel oddział bolszewicki. W starciu poległo 20 bolszewików, a 40 zostało wziętych do niewoli. Po opanowaniu Dunajowiec wysłano konne oddziały zwiadowcze w kierunku Nowej Uszycy. W południe doszło również do krótkiej walki ogniowej między ukraińską artylerią a bolszewickim pociągiem pancernym „Huragan”, który wkrótce wycofał się w kierunku Jarmoliniec ${ }^{123}$.

17 IX 1920 r. [w:] ibidem, s. 480; O. Udowyczenko, Tretja Zalizna..., s. 107-114; J. Legieć, Armia..., s. 165-166; B. Skrobacz, Kawałerija..., s. 184.

${ }_{121}$ Dok. Nr 505. Nakaz Wijśkam Dijewoji Armii UNR. cz. 175, Buczacz, 20 IX 1920 r. [w:] Ukrajinśko-moskowśka..., s. 235-236; Dok. Nr 509. Komhrup Henerału Zahrodśkomu, Komdiwu Okremoji Kinnoji cz. 172, Czortków, 22 IX 1920 r. [w:] ibidem, s. 238; Dok. Nr 462. Rozkaz do wojsk Armii Czynnej URL, Buczacz, 20 IX 1920 r. [w:] Bitwa wolyńsko-podolska..., s. 556; Dok. Nr 508. [Rozkaz] do dowódcy Grupy gen. Zagrodzkiego [i] dowódcy Samodzielnej Dywizji Konnej, Czortków, 22 IX 1920 r. [w:] ibidem, s. 618; O. Udowyczenko, Tretja Zalizna..., s. 115-117.

122 Dok. Nr 510. Operatywnyj zwit do 16 hodyn 22 weresnia 1920 r.cz. 01115, Czortków, 22 IX 1920 r. [w:] Ukrajinśko-moskowśka..., s. 238; O. Udowyczenko, Tretja Zalizna..., s. $117-118$.

123 Dok. Nr 523. Operatywnyj zwit do 6 hodyn 25 weresnia 1920 r. cz. 01122, Czortków, 25 IX 1920 r. [w:] Ukrajinśko-moskowśka..., s. 244; Dok. Nr 529. Operatywnyj zwit do 12 hod. 26 weresnia cz. 01126, Czortków, 26 IX 1920 r. [w:] ibidem, s. 247; O. Udowyczenko, Tretja Zalizna..., s. 118-120; Legieć, Armia..., s. 170-171. 


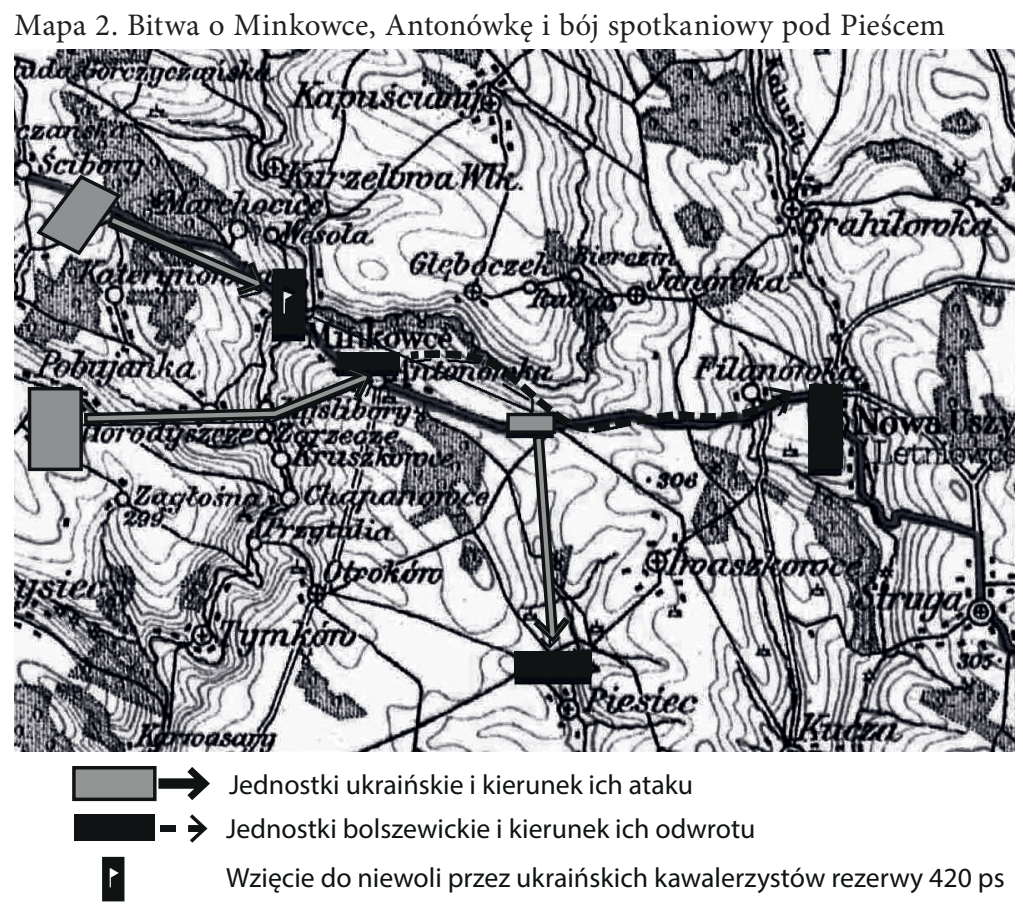

Autor: M. B. Kozubel. Źródło mapy: http://rzecz-pospolita.com.

24 września 1920 r. pod Dunajowcami rozbito oddział bolszewicki liczący wg ukraińskich danych ok. 400 bagnetów. Od jeńców dowództwo 3 Żelaznej DS dowiedziało się o rozmieszczeniu w Minkowcach zgrupowania przeciwnika w sile ok. 500 bagnetów, 200 szabel, 11 karabinów maszynowych i 2 dział oraz kolejnym oddziale bolszewickim w Nowej Uszycy, liczącym ok. 700 bagnetów i 200 szabel. Dwa dni później 8 Sotnia Konna płk. Marenhowskiego zajęła Jarmolińce i nawiązała kontakt z 4 Dywizją. W tym czasie 3 pk, wspierany pod koniec dnia przez VIII Brygadę (bez jej kawalerii), próbował bezskutecznie zająć Minkowce. Bolszewicy ponieśli jednak bardzo ciężkie straty. 3 DS wzięła do niewoli 320 żołnierzy wroga z 420 p. strz. ${ }^{124}$

27 września 1920 r. VIII Brygada i 3 pk, wspierane przez ogień artyleryjski 3 ukraińskich baterii, zaatakowały Minkowce. Bolszewicy wycofali się z miasta, a kawaleria ukraińska kontynuowała pościg za nimi, podczas gdy VIII Brygada zajęła Antonówkę. „Czerwoni” stracili ok. 300-500 poległych i rannych, a liczba wziętych do niewoli żołnierzy wyniosła ok. 450.

124 Dok. Nr 530. Rozwidocznyj zwit Sztadarmu UNR. 26. IX. 920 r. 19 hodyn cz. 245/rz., b.m., 26 IX 1920 r. [w:] Ukrajinśko-moskowśka..., s. 248; Dok. Nr 558. Meldunek operacyjny do godz. 16.00, Czortków, 24 IX 1920 r. [w:] Bitwa wołyńsko-podolska..., s. 681; Dok. Nr 559. Komunikat operacyjny sztabu Armii URL [z] 24 IX 1920 r., b.m., 24 IX 1920 r. [w:] ibidem, s. 681; Dok. Nr 591. Komunikat operacyjny Sztabu Armii URL [z] 26 IX 1920 r., b.m., 26 IX 1920 r. [w:] ibidem, s. 716; O. Udowyczenko, Tretja Zalizna..., s. 123. 
Następnego dnia 3 pk stoczył bój spotkaniowy ze zgrupowaniem bolszewickim (m.in. batalion z 420 p. strz., 1 pk) w pobliżu wsi Piesiec. Kawalerię Frołowa wsparła ogniem swej artylerii VII Brygada. Do niewoli dostało się 200 żołnierzy przeciwnika, a w ręce Ukraińców wpadł sztandar jednej $\mathrm{z}$ jednostek bolszewickich ${ }^{125}$.

29 września 1920 r. dowództwo Armii URL ogłosiło mobilizację na odbitych terenach zachodniego Podola. Dla 3 Żelaznej DS wyznaczono rejon Dunajowiec. Na froncie pozostawiono 3 pk, 7 i 8 Sotnie Konne, podczas gdy 9 Sotnia Konna została wyznaczona do działań rozpoznawczych. Wywiad ukraiński doniósł o obecności w Nowej Uszycy i okolicach 363 i 420 p. strz. w sile do ok. 3 tys. bagnetów i 200 szabel. Następnego dnia do płk. Frołowa przyszła dwuosobowa delegacja z jednej z kompanii 420 p. strz., chcąca wynegocjować warunki poddania się. Delegaci, Ukraińcy pochodzący z okolic Humania, poinformowali swoich rodaków z Armii URL o opuszczeniu Nowej Uszycy przez większość sił bolszewickich. Po zaakceptowaniu ich propozycji przez Frołowa delegaci wrócili do Nowej Uszycy, gdzie zastali swą kompanię okrążoną przez inny oddział Armii Czerwonej. Z tego powodu zbiegli do miejsca stacjonowania $3 \mathrm{pk}$, po czym wstąpili w szeregi 3 DS. Wiadomość o odwrocie bolszewików okazała się fałszywa. W rejon Nowej Uszycy dotarło uzupełnienie dla oddziałów przeciwnika w sile kilkuset bagnetów ${ }^{126}$.

Na odcinku zajmowanym przez 3 Żelazną DS sytuacja chwilowo się uspokoiła. 30 września 1920 r. jej stan żywieniowy wynosił 834 oficerów, 3613 kozaków, 2442 konie $^{127}$. Na początku października 1920 r. stawało się pewne, że szybko dojdzie do rozmów polsko-bolszewickich dotyczących rozejmu. Z tego powodu dowództwo Armii Czynnej URL zdecydowało o wznowieniu działań ofensywnych w celu odbicia jak największej części terenu Podola z rąk przeciwnika przed zawarciem rozejmu. 3 października 3 DS uderzyła z powodzeniem na wsie Barsukowce, Iwaszkowce i Braiłówkę. Kawaleria dywizyjna zajęła również Nową Uszycę. Następnego dnia, nad ranem, piechota bolszewicka uderzyła na pozycje ukraińskie pod Nową

125 Dok. Nr 537. Rozwidocznyj zwit Sztadarmu UNR. 27. IX. 920 r. do 20 hodyn cz. 248/ rz., b.m., 27 IX 1920 r. [w:] Ukrajinśko-moskowśka..., s. 250; Dok. Nr 538. Operatywnyj zwit do 20 hodyn 27 weresnia 1920 r. cz. 01130, Czortków, 27 IX 1920 r. [w:] ibidem, s. 251; Dok. Nr 546. Operatywnyj zwit do 12 hodyn 29-ho weresnia cz. 01135, Czortków, 29 IX 1920 r. [w:] ibidem, s. 254; O. Udowyczenko, Tretja Zalizna..., s. 123-126; B. Skrobacz, Kawałerija..., s. 184 .

126 Dok. Nr 548. Rozwidocznyj zwit Sztadarmu UNR 29-9-920 cz. 252/rz, b.m., 29 IX 1920 r. [w:] Ukrajinśko-moskowśka..., s. 255; Dok. Nr 551. Rozwidocznyj zwit Sztadarmu UNR. 30 IX 1920, 10 hod. cz. 253/rz, b.m., 30 IX 1920 r. [w:] ibidem, s. 256; Dok. Nr 554. Rozwidocznyj zwit Sztadarmu UNR 30-IX-1920 20 hodyn cz. 254/rz, b.m., 30 IX 1920 r. [w:] ibidem, s. 258; O. Udowyczenko, Tretja Zalizna..., s. 126.

127 CDAWOWUU, f. 1075, op. 2, sp. 381, Charczowyj stan starszyn, kozakiw ta konnej Armiji U.N.R. po składu na 30 weresnja 1920 r., b.m. 30 IX 1920 r., k. 136. 
Uszycą. Atak został odparty, a za wycofującym się przeciwnikiem ruszyła w pościg kawaleria Frołowa. Bolszewicy stracili 60 zabitych, 80 wziętych do niewoli oraz 2 karabiny maszynowe ${ }^{128}$.

5 października 1920 r. 3 Żelazna DS przeszła do natarcia w kierunku na wschód od Nowej Uszycy. Uderzono na linii Iwankowce-Kucza-Braiłówka. 8 Sotnia Konna zajęła Zamiechów, gdzie w walce poległo ok. 150 bolszewików z 362 p. strz. Do końca dnia 3 Żelazna DS osiągnęła linię StrugaZamiechów-Żabińce. W dniach 6-8 października bolszewicy próbowali bezskutecznie wyprzeć Ukraińców z zajętych pozycji. Najsilniejszy atak, z dnia 7 października, skierowano na pozycje VIII Brygady, którą potem wsparła IX Brygada, pod Zamiechowem. Bolszewicy stracili tam ponad 200 zabitych i ok. 300 wziętych do niewoli. 8 października ponownie zaatakowano pozycje VIII Brygady. Tego dnia udało się „czerwonym” czasowo wyprzeć Ukraińców z Zamiechowa. Silnym kontratakiem VIII i IX Brygady ponownie wyparły przeciwnika z tej miejscowości ze stratami wynoszącymi ponad 100 poległych, 190 jeńców oraz 4 karabiny maszynowe. W czasie walk o Zamiechów po stronie ukraińskiej poległo 8 oficerów i 42 kozaków, rannych zostało ok. $100^{129}$.

Pawło Szandruk, dowódca VII Brygady, wspominał: „Wróg wycofywał się w panice, a nasze dowództwo w pełni wykorzystało sytuację. Co prawda wkrótce bolszewicy rzucili przeciwko nam świeże oddziały, my jednak rozumieliśmy, że pomimo naszego wyczerpania musimy posuwać się naprzód tak szybko, jak tylko to możliwe, wykorzystując przewagę naszego morale. Znów powtarzało się jedno i to samo: walki, forsowne marsze, praca organizacyjna"130.

W dniach 10-13 października 1920 r. 3 Żelazna DS znowu toczyła ciężkie walki z przeciwnikiem o rejon Zamiechowa. 10 października VIII Brygada odparła wszystkie ataki bolszewickie, które zakończyły się wieczorem, gdy zapadający zmrok uniemożliwił skuteczne prowadzenie działań ofensywnych.

128 Dok. Nr 568. Operatywna. Komhrup. Serednioji, kopija Komdiw Kułemetnoji., b.m., 3 X 1920 r. [w:] Ukrajinśko-moskowśka..., s. 264; Dok. Nr 571. Operatywnyj zwit do 16 hod. 4-ho żowtnia cz. 01144, Gródek, 4 X 1920 r. [w:] ibidem, s. 266; Dok. Nr 572. Operatywnyj zwit do 8 hod. 5 żowtnia cz. 01145, Gródek, 5 X 1920 r. [w:] ibidem, s. 266; Dok. Nr 729. Komunikat operacyjne Sztabu Armii URL [z] 3 X 1920 r., b.m., 3 X 1920 r. [w:] Bitwa wotyńsko-podolska..., s. 861; O. Udowyczenko, Tretja Zalizna..., s. 127.

129 Dok. Nr 575. Operatywnyj zwit do 18 hod. 5 żowtnia 1920 r. cz. 01146, Gródek, 5 X 1920 r. [w:] Ukrajinśko-moskowśka..., s. 268-269; Dok. Nr 577. Nehajno. Komhrup Serednioji Komhrupy Prawoji cz. 201/op, Gródek, 5 X 1920 r. [w:] ibidem, s. 269-270; Dok. Nr 587. Operatywnyj zwit do 12 hodyn 8 żowtnia 1920 r. cz. 01151, Gródek, 8 X 1920 r. [w:] ibidem, s. 274-275; Dok. Nr 822. Komunikat operacyjny Sztabu Armii URL [z] 8 X 1920 r., b.m., 8 X 1920 r. [w:] Bitwa wolyńsko-podolska..., s. 970; Dok. Nr 834. Meldunek operacyjny do godz. 8.00, Gródek Podolski, 9 X 1920 r. [w:] ibidem, s. 981-982; O. Udowyczenko, Tretja Zalizna..., s. 128-132.

130 P. Szandruk, Siła..., s. 112. 
Rannych zostało 3 kozaków. 11 października bolszewicy ponownie uderzyli na Zamiechów. Tego dnia do walki włączyła się jednak IX Brygada, która uderzyła na wieś Pilipkowce, wprowadzając tym samym zamęt w szeregach przeciwnika. Atak „siostrzanej” brygady umożliwił przeprowadzenie skutecznego kontrataku. Jeden z kureni VIII Brygady w pościgu za „czerwonymi” dotarł do wsi Woronowce, został jednak spod niej wyparty. Bolszewicy nie pozostawali bierni. Zaatakowali pozycje 19 kurenia z VII Brygady, zajmując wieś Durniaki, kontrakcja pozostałych kureni przyczyniła się do odzyskania tej pozycji. VIII Brygada straciła tego dnia 2 zabitych i 13 rannych, a VII Brygada 6 rannych. 12 października charakteryzował się mniej gwałtownymi atakami na pozycje 3 DS. Wpływ na to miały zarówno duże straty bolszewików, jak i sytuacja na pozostałych odcinkach frontu. Następnego dnia dywizja gen. Udowyczenki przy wsparciu SDK przeszła do natarcia, chwilowo zajmując Kuryłowce Murowane. Ostatniego dnia walk o Zamiechów 3 Żelazna DS straciła 11 poległych kozaków oraz 8 oficerów i 56 kozaków, którzy zostali ranni ${ }^{131}$.

Choć 3 DS pozostała najsilniejszym związkiem taktycznym Armii Czynnej, to ciągłe walki odcisnęły się na jej liczebności oraz możliwości uzupełnienia strat. Ukraińcy musieli opanować większą część Podola, aby przeprowadzić skuteczną mobilizację. Dowódca VII Brygady, Pawło Szandruk, następująco opisał najpoważniejszy problem wojsk ukraińskich: „Brygada była w kiepskim stanie. Niezależnie od naszych udanych prób rozbicia wroga przy jak najmniejszych stratach własnych, straty po naszej stronie rosły. Niektóre bataliony [tj. kurenie] liczyły nie więcej jak 50-60 osób, 12. batalion miał ponad setkę ludzi, a szwadron kawalerii - trzydzieści koni. Mieliśmy nadzieję, że wróg nie będzie w stanie przeszkodzić przeprowadzeniu przez nas

131 Dok. Nr 602. Operatywnyj zwit do 8 hodyn 11 żowtnia cz. 01157, Gródek, 11 X 1920 r. [w:] Ukrajinśko-moskowśka..., s. 280; Dok. Nr 609. Operatywnyj zwit do 20 hodyn 12 żowtnia cz. 0184, Gródek, 12 X 1920 r. [w:] ibidem, s. 283; Dok. Nr 613. Operatywnyj zwit Sztandarm UNR do 18 hod. 13/X 20 r. cz. 1162, Gródek, 13 X 1920 r. [w:] ibidem, s. 285; Dok. Nr 877. Meldunek operacyjny do godz. 8.00, Gródek Podolski, 11 X 1920 r. [w:] Bitwa wołyńsko-podolska..., s. 1032; Dok. Nr 880. Komunikat operacyjny Sztabu Armii URL [z] 11 X 1920 r., b.m., 11 X 1920 r. [w:] ibidem, s. 1034; Dok. Nr 897. Komunikat operacyjny Sztabu Armii URL [z] 12 X 1920 r., b.m., 12 X 1920 r. [w:] ibidem, s. 1052; Dok. Nr 911. Meldunek operacyjny do godz. 18.00, Gródek Podolski, 13 X 1920 r. [w:] ibidem, s. 1067; Dok. Nr 912. Meldunek operacyjny Sztabu Armii, Gródek Podolski, 13 X 1920 r. [w:] ibidem, s. 1068; Dok. Nr 913. Komunikat operacyjny Sztabu Armii URL [z] 13 X 1920 r., b.m., 13 X 1920 r. [w:] ibidem, s. 1069; O. Udowyczenko, Tretja Zalizna..., s. 133-139. Bardzo duża liczba zabitych po stronie bolszewickiej była wynikiem głównie ataków ukraińskiej kawalerii, która też niechętnie brała jeńców. Poza tym nieprzygotowani psychicznie na szarże wrogiej kawalerii rekruci Armii Czerwonej często rzucali się do ucieczki na widok atakujących kozaków. W trakcie pościgów ginęło najwięcej żołnierzy strony wycofującej się. Warto przy tym dodać, że kozacy płk. Frołowa znaleźli przy jeńcach naboje rozrywające, co dodatkowo oddaje brutalność walk toczonych między Ukraińcami a bolszewikami; ibidem, s. 126-127. 
mobilizacji nowych rekrutów w tym rejonie, liczyliśmy także na to, że Polacy będą mieli większe możliwości zaopatrywania nas w broń"132.

Na 14 października 1920 r. 3 Żelazna DS otrzymała zadanie zdobycia Kuryłowiec Murowanych, Bachtynia i Dereszowa. Jej stan żywieniowy tego dnia wynosił 763 oficerów, 4144 kozaków, 1704 urzędników wojskowych i innych pracowników cywilnych oraz 2618 koni (w tym 813 wierzchowców). Stan bojowy sięgał z kolei 375 oficerów, 1381 bagnetów, 606 szabel, 112 karabinów maszynowych (238 kozaków obsługi) i 14 dział. Na jej wyposażeniu znajdowało się również 560 wozów i 4 samochody. Na pierwszą z miejscowości uderzyła VII Brygada, jednak nie była ona w stanie wyprzeć z niej przeciwnika. VIII Brygada zajęła Bachtyń oraz przy wsparciu 9 Sotni Konnej wieś Krzywochyżyńce. Do wieczora IX Brygada wyparła bolszewików z południowej części Michajłowiec. Następnego dnia w działaniach bojowych wzięła udział głównie kawaleria dywizyjna, która zajęła Kotiużany. VII Brygada do wieczora osiągnęła linię Równe-Perekoryńce-Olczydajów Wyższy, a IX Brygada zajęła pozostałą część Michajłowiec, zdobywając również 2 działa ${ }^{133}$.

W skutek ostatnich starć istotnie zmalały zapasy amunicji 3 Żelaznej DS. Oficerowie i kozacy byli wyczerpani mimo stosunkowo niewielkich strat poniesionych przez dywizję. Zdecydowanie negatywnie na morale Ukraińców wpłynęła jednak wiadomość o zawieszeniu broni, które miało wejść w życie 18 października o godz. 24:00. Od 16 października 3 DS prowadziła natarcie w kierunku rzeki Murafa oraz miast Szarogród i Łuczyniec. Do 19 października dywizji udało się przy niewielkich stratach osiągnąć linię Borowce-Wołodyjowce-Dżuryn-Murafa. Tego też dnia do jednostki gen. Udowyczenki doszedł rozkaz o natychmiastowym zaprzestaniu działań bojowych ${ }^{134}$.

\section{Podsumowanie}

Po wejściu w życie rozejmu polsko-bolszewickiego Armia Czynna URL znalazła się w fatalnej sytuacji. Obszar opanowany przez petlurowców był niewielki, bez głębi operacyjnej. W wypadku przerwania frontu przez

132 P. Szandruk, Siła..., s. 112.

133 Dok. Nr 619. Operatywnyj zwit do 20 hodyn 14 żowtnia 1920 r. cz. 01167, Gródek, 14 X 1920 r. [w:] Ukrajinśko-moskowśka..., s. 288; Dok. Nr 621. Operatywnyj zwit do 12 hod. 15. X. 1920 r. cz. 01169, Gródek, 15 X 1920 r. [w:] ibidem, s. 288; O. Udowyczenko, Tretja Zalizna..., s. 139-141; A. Rukkas, Razem..., s. 245-246.

134 Dok. Nr 626. Nakaz Wijśkam Dijewoji Armii UNR. No 626 [w:] Ukrajinśko-moskowśka..., s. 291-292; Dok. Nr 636. Komdiwam 1, 2, 3, 4, 5, 6, Kułemetnoji, Kinnoji cz. 360, b.m., 18 X 1920 r. [w:] ibidem, s. 295-296; O. Udowyczenko, Tretja Zalizna..., s. 141-145; P. Szandruk, Siła..., s. 112; idem, Ukrainśka Armija w borotbi z Moskowszczynoju, „Za Derżawnist” (Kalisz) 1934, nr 4, s. 202; Z. Karpus, Wschodni..., s. 41; J. Legieć, Armia..., s. 177-178. 
bolszewików Armii Czynnej groziło znalezienie się w dwóch lub kilku kotłach i rozgromienie. Fatalna była również sytuacja $\mathrm{z}$ wyposażeniem i amunicją. Wiele karabinów wymagało napraw, a niektóre były już zużyte. Oficerowie Armii Czynnej URL zdawali sobie sprawę z niewielkich szans na zwycięstwo w samotnej walce z Armią Czerwoną. Jeden z nich, Szandruk, wspominał: „Stało się dla mnie całkiem jasne, że nasza walka przeciwko bolszewikom - biorąc pod uwagę potencjał czerwonej Moskwy - weszła w nowe stadium kryzysu. Wszystkie moje złe przeczucia odnośnie do naszej sytuacji i perspektyw zachowałem dla siebie, aby podtrzymać na duchu moich żołnierzy w nadziei rychłego wznowienia operacji, ponieważ rozejm został zawarty tylko do 10 listopada"135.

Nowe działania wojenne rzeczywiście zakończyły się klęską wojsk ukraińskich. Choć bolszewicy nie posiadali znacznej przewagi liczebnej, to jednak w pełni wykorzystali słabości przeciwnika. Po przerwaniu frontu przez Armię Czerwoną petlurowcy byli zmuszeni do odwrotu za Zbrucz, gdzie zostali rozbrojeni przez Wojsko Polskie i internowani. Tym samym zakończyła się epopeja regularnych sił zbrojnych URL. Od tego momentu główną rolę w walce z bolszewikami nad Dnieprem odgrywały ukraińskie formacje powstańcze, cywilne organizacje konspiracyjne oraz stworzony na początku 1921 r. Sztab Powstańczo-Partyzancki. Wymieniony organ odpowiadał za zorganizowanie nieudanego II Pochodu Zimowego - wypadu grup zorganizowanych $\mathrm{z}$ internowanych petlurowców na terytorium okupowane przez bolszewików - mającego na celu zainicjowanie antybolszewickiego powstania na Ukrainie ${ }^{136}$.

3 Żelazna Dywizja Strzelecka również wzięła aktywny udział w ostatniej, listopadowej kampanii Armii Czynnej URL. Jej żołnierze stawili zaciekły opór przeciwnikowi, jednak ich postawa nie mogła zmienić biegu wydarzeń. „Żelaźni” posmakowali tak porażki, jak i internowania. W następnym latach wielu z nich wzięło aktywny udział w życiu politycznym, społecznym i kulturalnym ukraińskich środowisk emigracyjnych. Część znalazła się w szeregach grup uczestniczących w II Pochodzie Zimowym. Sam gen. Udowyczenko wyjechał z Polski do Francji w 1924 r. Brał aktywny udział w polityce rządu emigracyjnego URL.

3 Żelazna Dywizja Strzelecka wniosła spory wkład w wojnie z bolszewikami. Była najsilniejszą formacją Armii URL, a w jej szeregach znalazło się wielu doświadczonych oficerów i kozaków, którzy służyli pod rozkazami Udowyczenki jeszcze w 1919 r. 3 Żelazna DS odniosła na polach walk w Galicji Wschodniej i na Podolu szereg sukcesów nad przeciwnikiem, często zadając mu ogromne straty (nawet biorąc pod uwagę to, że niektóre raporty zawyżały

\footnotetext{
135 P. Szandruk, Siła..., s. 112-113.

136 Więcej na temat II Pochodu Zimowego Armii URL zob. W. Weryha, Eystopadowyj Rejd 1921 roku, Kyjiw 2011.
} 
rozmiar sukcesów) ${ }^{137}$. Sama straciła w walkach co najmniej 592 zabitych, rannych i zaginionych ${ }^{138}$. Po zapoznaniu się ze szlakiem bojowym formacji, tak w 1919, jak i 1920 r., nie dziwi to, że dowództwo Armii URL nadało jej miano „Żelaznej”.

\section{Bibliografia}

\section{Archiwalia}

Centralnyj Derżawnyj Archiw Wyszczych Orhaniw Włady ta Uprawlinnja Ukrajiny u Kyjewi

Fond 1075: Wijśkowe ministerstwo Ukrajinśkoji Narodnoji Respubliky Fond 1078: Hołowne uprawlinnja Heneralnoho sztabu UNR

\section{Źródła drukowane}

Bitwa lwowska 25 VII-18 X 1920. Dokumenty operacyjne, t. I: 25 VII-5 VIII, oprac. zesp. pod kier. M. Tarczyńskiego, Warszawa 2002; t. II: 6-20 VIII, oprac. zesp. pod kier. M. Tarczyńskiego, Warszawa 2004.

Bitwa o Ukrainę 1 I - 24 VII 1920. Dokumenty operacyjne, t. I: 1 I - 11 V 1920, oprac. zesp. pod kier. M. Tarczyńskiego, Warszawa 2016.

Bitwa wołyńsko-podolska 5 IX-21 X 1920. Dokumenty operacyjne, oprac. zesp. pod kier. M. Tarczyńskiego, Warszawa 2014.

Docenko O., Zymowyj pochid (6.XII.1919 - 6.V.1920), Kyjiw 2001.

Grażdanskaja wajna na Ukrainie 1918-1920. Sbornik dokumentów i materiałów $w$ triech tomach, czetyriech knigach, t. III, oprac. N. Kolesnik, Kiew 1967.

Ukrajinśko-moskowśka wijna 1920 r., oprac. W. Salski i P. Szandruk, Warszawa 1933.

\section{Wspomnienia}

Babel I., Dziennik 1920, Warszawa 1990.

Kukiel M., Moja wojaczka na Ukrainie - wiosna 1920: dziennik oficera sztabu generalnego, wstęp i oprac. J. Zuziak, Warszawa 1995.

Romer J., Pamiętniki, Warszawa 2011.

Szandruk P., Siła męstwa, Warszawa 2014.

${ }^{137}$ Jeśli wierzyć raportom z pola walki, które często zawierały ogólnikowe oraz zawyżone dane o stratach przeciwnika, jednostki Armii Czerwonej straciły w walkach z 3 Żelazną DS co najmniej 4 tys. zabitych, rannych i jeńców. Moim zdaniem są one zawyżone, nawet biorąc pod uwagę to, że w drugiej połowie sierpnia i we wrześniu żołnierze bolszewiccy byli brani do niewoli dość licznie, a wiele ataków na pozycje ukraińskie kończyło się fatalnie dla „czerwonych” oddziałów. Według mojej opinii rzeczywiste straty Armii Czerwonej w walce z „Żelaznymi” były mniejsze o ok. 1-1,5 tys. zabitych, rannych i wziętych do niewoli.

${ }_{138}$ Ustalenie dokładnych strat 3 Żelaznej DS może być trudne z uwagi na brak pełnej dokumentacji archiwalnej, a także ogólnikowość niektórych raportów - bywało, że ich autorzy podawali tylko łączną liczbę poległych, rannych i zaginionych. Myślę, że całkowite straty poniesione przez 3 Żelazną DS od 8 III do 18 X 1920 r. mogły sięgnąć ok. 700-750 zabitych, rannych i zaginionych. 
Udowyczenko O., Tretja Zalizna dywizja. Materiały do istorii Wijśka Ukrainśkoji Narodnoji Respubłyky. Rik 1919, New York 1971.

Udowyczenko O., Tretja Zalizna dywizja. Materiały do istorii Wijśka Ukrainśkoji Narodnoji Respubłyky. Rik 1920, New York 1982.

\section{Opracowania}

Bruski J. J., Petlurowcy. Centrum Państwowe Ukraińskiej Republiki Ludowej na wychodźstwie (1919-1924), Kraków 2000.

Karpus Z., Jeńcy i internowani rosyjscy i ukrainscy na terenie Polski $w$ latach 1918-1924, Toruń 2002.

Karpus Z., Wschodni sojusznicy Polski w wojnie 1920 roku: oddziały wojskowe ukraińskie, rosyjskie, kozackie i białoruskie w Polsce w latach 1919-1920, Toruń 1999.

Klimecki M., Galicja Wschodnia 1920, Warszawa 2005.

Klimecki M., Lwów 1918-1919, Warszawa 1998.

Klimecki M., Polsko-ukraińska wojna o Lwów i Galicję Wschodnią 1918-1919, Warszawa 2000.

Legieć J., Armia Ukraińskiej Republiki Ludowej w wojnie polsko-ukraińsko-bolszewickiej w 1920 r., Toruń 2002.

Łytwyn M., Ukrajinśko-polśka wijna 1918-1919 rr., Lwiw 1998.

Sojka-Mastalerz H., Rusini czy Ukraincy? Językowy obraz nacji ukraińskiej w prasie polskiej (1918-1939), Wrocław 2004.

Pisuliński J., Nie tylko Petlura. Kwestia ukrainska w polskiej polityce zagranicznej w latach 1918-1923, Wrocław 2004.

Potocki R., Idea restytucji Ukraińskiej Republiki Ludowej: (1920-1939), Lublin 1999.

Rukkas A., Razem $z$ Wojskiem Polskim. Armia Ukrainskiej Republiki Ludowej w 1920 r., Warszawa 2020.

Skrobacz B., Kawałerija zbrojnych sył UNR u polśko-radjanśkij wijni 1920 r. ta osobływosti jiji zastosuwannja w oboronnych bojach i kontrnastupi (traweńżowteń 1920 r.), „Wijśkowo-naukowyj żurnał” 2008, nr 10.

Skrukwa G., Formacje wojskowe ukraińskiej „rewolucji narodowej” 1914-1921, Toruń 2008.

Szajdak S., Polsko-ukraiński sojusz polityczno-wojskowy w 1920 roku, Warszawa 2005.

Szandruk P., Ukrainśka Armija w borotbi z Moskowszczynoju, „Za Derżawnist” (Kalisz) 1934, nr 4.

Ślipiec J., Drogi niepodległości - Polska i Ukraina 1919-1921, Warszawa 1999.

Udowyczenko O., Forsuwannja Dnistra pid Horodnyceju, „Za Derżawnist” (Kalisz) 1934, $\mathrm{nr} 4$.

Weryha W., Łystopadowyj Rejd 1921 roku, Kyjiw 2011.

Wiszka E., Jak przekazywać teksty ukrainskie w języku polskim?, „Nad Wisłą i Dnieprem. Polska i Ukraina w przestrzeni europejskiej - przeszłość i teraźniejszość" (Toruń-Kijów) 2002, nr 1.

Wiszka E., Szósta Strzelecka. Szósta Siczowa Dywizja Strzelecka Armii Ukraińskiej Republiki Ludowej. Formowanie, szlak bojowy, internowanie 1920-1924, Toruń 2012. 


\section{STRESZCZENIE}

\section{Marek Bogdan Kozubel, 3 Żelazna Dywizja Strzelecka Armii Ukraińskiej Republiki Ludowej w 1920 r. Zarys szlaku bojowego w wojnie polsko-bolszewickiej}

Tematem artykułu jest szlak bojowy 3 Żelaznej Dywizji Strzeleckiej Armii Ukraińskiej Republiki Ludowej w ostatnim roku wojny polsko-bolszewickiej. Wspomniana formacja była najsilniejszą i najliczniejszą w ukraińskich siłach zbrojnych w $1920 \mathrm{r}$. Dowodził nią Ołeksander Udowyczenko, słynny i bardzo utalentowany oficer. Należy dodać, że 3 Żelazna Dywizja Strzelecka została początkowo sformowana u boku Wojska Polskiego jako 2 Dywizja Strzelecka, ale z uwagi na obecność w jej szeregach wielu weteranów 3 Dywizji Żelaznej z 1919 r., którą również dowodził Udowyczenko, zdecydowano się na zmianę nazwy formacji.

3 Żelazna Dywizja Strzelecka wzięła aktywny udział w wyprawie kijowskiej wiosną 1920 r. Walczyła wtedy na południowym odcinku frontu w rejonie Mohylewa Podolskiego. Później, latem 1920 r., brała udział w obronie Galicji Wschodniej przed Armią Czerwoną. Odniosła tam szereg sukcesów w walce z bolszewikami, m.in. pod Sidorowem i Horodenką. Następnie uczestniczyła w dalszych działaniach bojowych na Podolu.

Po 18 października 1920 r. Armia URL musiała kontynuować walkę samodzielnie z uwagi na podpisanie zawieszenia broni pomiędzy Polską a Rosją bolszewicką. Prowadzone do drugiej połowy listopada 1920 r. działania wojenne zakończyły się porażką Ukraińców, których siły zbrojne wycofały się na terytorium państwa polskiego, gdzie zostały internowane. W tej grupie znaleźli się również żołnierze 3 Żelaznej Dywizji Strzeleckiej.

Słowa kluczowe: 3 Żelazna Dywizja Strzelecka, wojna polsko-bolszewicka, wyprawa kijowska, Armia Czynna, Galicja

\section{SUMMARY}

\section{Marek Bogdan Kozubel, 3rd Iron Rifle Division of the Ukrainian People's Republic Army in 1920. Outline of the Battle Route in the Polish-Bolshevik War}

The subject of the article is the battle route of the 3rd Iron Rifle Division of the Ukrainian People's Republic Army in the last year of the Polish-Soviet war. This formation was the strongest and most numerous in the Ukrainian armed forces in 1920. It was commanded by Oleksandr Udovychenko, a famous and very talented officer. It should be noted that the 3rd Iron Rifle Division was initially formed at the Polish Army as the 2nd Rifle Division, but due to the presence of many veterans of the 3rd Iron Division of 1919 in its ranks, which was also commanded by Udovychenko, it was decided to rename the formation.

The 3rd Iron Rifle Division took an active part in the Kiev expedition in the spring of 1920. It fought on the southern section of the front in the Mohyliv-Podilskyi 
area. Later, in the summer of 1920, it took part in the defense of Eastern Galicia against the Red Army. It succeeded in several fights against the Bolsheviks there, among others at Sydoriv and Horodenka. Then it participated in further combat activities in Podolia.

After 18 October 1920, the Ukrainian People's Republic Army had to continue fighting on its own due to the signing of a ceasefire between Poland and Soviet Russia. The warfare conducted until the second half of November 1920 ended in defeat for the Ukrainians, whose armed forces withdrew to the Polish territory, where they were interned. In this group there were also soldiers of the 3rd Iron Rifle Division.

Keywords: 3rd Iron Rifle Division, Polish-Bolshevik war, Kiev expedition, Ukrainian People's Army, Galicia

\section{АННОТАЦИЯ \\ Марек Богдан Козубель, Третья Железная стрелковая дивизия армии Украинской Народной Республики в 1920 году. Очерк боевого пути в польско-большевистской войне.}

Предметом статьи является боевой путь 3-й стрелковой дивизии Украинской Народной Республики в последний год польско-большевистской войны. Данное подразделение было самым сильным и многочисленным в украинских вооруженных силах в 1920 году. Командовал им Олександр Удовиченко, известный и очень талантливый офицер. Следует добавить, что 3-я железная стрелковая дивизия изначально была сформирована при польской армии как 2-я стрелковая дивизия, но из-за присутствия в ней многих ветеранов 3-й железной дивизии с 1919 года, которой также руководил Удовиченко, было решено изменить название подразделения.

Весной 1920 года 3-я стрелковая дивизия принимала активное участие в Киевской операции. В то время она воевала на южном участке фронта в районе Могилева-Подольского. Позже, летом 1920 года, она участвовала в обороне Восточной Галиции от Красной Армии. Там она добилась ряда успехов в борьбе с большевиками, в т.ч. под Сидоровым и Городенкой. После этого дивизия участвовала в дальнейших боевых действиях на Подолье.

После 18 октября 1920 года Армия УНР была вынуждена продолжать борьбу самостоятельно из-за подписания соглашения о прекращении огня между Польшей и большевистской Россией. Боевые действия, которые велись до второй половины ноября 1920 г., закончились поражением украинцев, вооруженные силы которых отошли на территорию Польского государства, где и были интернированы. В их число входили также солдаты 3-й Железной стрелковой дивизии.

Ключевые слова: 3-я Стрелковая дивизия, Польско-большевистская война, Киевская операция, Армия УНР, Галиция 